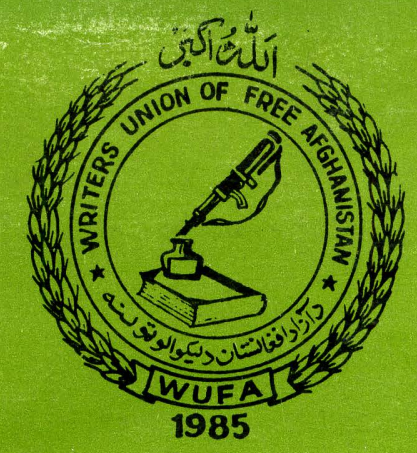

\title{
Volume 1 Number 1
} 1985
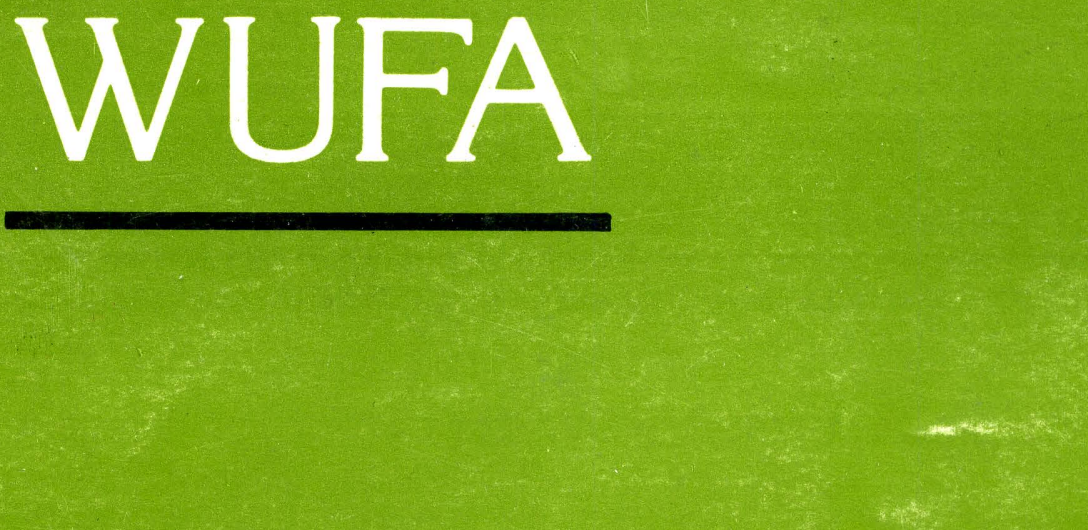


\section{WUFA}

\section{Editorial Board}

Prof. A. Rasul Amin

Dr. Z.A. Mumtaz

Ahmad Yosuf Noristani

Hakim Taniwal

Major Nasrullah Safi

Abdul Hai Warshan

\section{Postal Address:}

Post Box No. 867

Peshawar University (NWFP)

Pakistan.

Price per Copy Rs. 25.00 


\section{WUFA}

VOLUME 1 NUMBER 1

1985

Contents

FOREWORDS, What a Brutal Assault ARTICLES

Page

Soviet Military Tactics in Afghanistan

Major Naspullah Safi

Unity is the Remedy

A. Rasul Amin

Soviet Aggression of Afghanistan

Dr. Z.A. Mumtaz

Coordination Leads to Success

D. M. Khalil

Who cares for Afghanistan?

Jamila Luijckx and G.J. Wennik

A Protracted Warfare Ahead

33

M. Hakim Aryubi.

Pushtun Tribes and the Afghan Resistance

H. Taniwal and A.Y. Nuristani

M. Asef Ikram

Introduction to Animal Farm

61

A. Rasul Amin

Writers of the Articles 


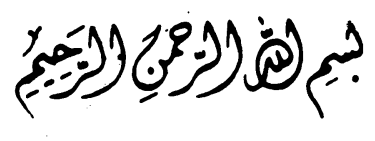

FOREWORD

What a Brutal Assault!

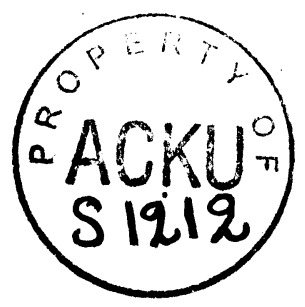

Throughout Afghan histroy, many conquerors have trodden Afghanistan to use this strategic land as a crossroad for the extension of their empires. Changiz Khan, Holaku Khan and others have invaded this land and have left behind carnage and complete destruction of the centres of past civilisations in Afghanistan on their way to conquest.

Like their forefathers, the inhabitants of this soil have stood in front of the Soviets, the true inheritors of universal empire builders, to keep the integrity, independence and sovereignty of their home-land intact as their ancestors have done throughout the ages. But there are great differences between former invaders and the Soviets. The former hordes used horses, swords, spears and other simple instruments in their warfare. They crossed through a few beaten tracks in the mountains and plains and killed those who resisted them on their route to conquest. The intruders did not divert their course to chase the resistants up in the mountains or in the far away plains.

Contrary to the former conquerors, the present invaders are armed with the most sophisticated weaponry, in the service of communist ideology for world domination. They can reach easily the far away plains and skyhigh mountains in every corner of Afghanistan either by road or by air.

None of the inhabitants of liberated areas, whether in hermits or villages, nor suspects in occupied towns and cities, feel themselves safe and secure from the Soviet bombardment, destruction, torture or killing. Even forced depopulation policy is being carried out by the invaders to drain the support of the mujahideen inside the country and to create economic and social problems for the neighbouring Muslim countries - Pakistan and Iran.

The Soviet dictators have a single criterion for their judgment. Either you are comrade in arms sympathetic to the communist regime, or, you are class enemy. On this basis, the Soviet proxies, Khalq/Parcham, declared a one party war against all sectors of Afghan society. Since 27, April, 1978 till now hundreds of Afghans on numerous charges of being reactionary, nationalist, chauvinist, bourgeois, feudal, anti - ideology, anti-state, foreign agents, collaborators, thieves, saboteurs etc are put in torture cells and many 
of them summarily executed. To the Soviets, human beings are nothing more than wax dummies. This is why they have resolved to force all the Afghan people, who have a quite different socio-relgious and politicoeconomic life, into the Soviet mould and to get them adjusted in the length and width of it. This mould, made in their images, lies in numerous torture cells of prisons, espionage networks, centres of state-sponsored terrorists and death squads. In less than eight years, this mould has swallowed more than one million Afghans from all walks of life an its spectre has forced millions either to migrate outside or run inside the country for their safety.

PROPAGANDA ASSAULT:

In addition to their brutal measures to maintain military control over Afghanistan, the Soviet planners and their surrogates are busily at work laying the foundation for a new Afghanistan, modelled on the Soviet Ceneral Asian Republics. A basic step for this transformation has been the Soviet monopoly of all sources of information in Afghanistan where all broadcasting, press and educational institutions regulate strictly what the invaded Afghans should read and hear and, over time, how they should view their history and themselves through Soviet-made glasses.

Research institutions, compilation and translation bureaus, curriculum departments and propaganda centres in Moscow, Kabul and Tashkent are the main wheedles of this apparatus to sovietise the minds of the Afghan people in general and of the young generation in particular. All these institutions prepare Soviet-oriented historical, economic, ideological and political tracts, textbooks and all sorts of literary works in Pashto, Dari and other languages for sovietisation. The task has been assigned to party-directed state scholars to reconsider Afghan history, culture, religion, politics, the socio-economic structure of the society and so on in a Marxist-Leninist perspective in order to legitimise an unpopular regime, an illigal invasion and alienate the young generation from the main stream of their country's old cultural and national heritage. The products of this gigantic Soviet propaganda machine floods the books stalls, educational institutions and propaganda centres in Kabul and other occupied areas in order to spread Soviet-style communism and to explain each dimension of the Afghan crisis according to the Soviet-line.

The Soviet educationists prepare texts for school children in Afghanistan, in various civilian and military educational institutions, to impart the rudiments of communist ideology, from elementary schools up to their higher studies. Most of the students are recruited for the army, secret police, party activists, propaganda agents etc. The activities of the students, recruited in the special youth brigades, are to spread disinformation and propaganda for the communist ideology against the social, political religious, and cultural norms of Afghan society. They also guard Government institutions and are engaged in vigilant espionage in the neighbourhood. Moreover, thousands of 
Afghan students, bureaucrats, military cadets, officers and representatives of all walks of life are annaully being sent to the Central Asian and other Soviet Republics as well as to the satellite countries of communist bloc for training and indoctrination in the principles of Soviet-style Marxism-Leninism and demonstrations in show-cases of progress under the communist regime.

In order to speread communist ideology beyond the educated elite in Kabul and other occupied cities, the broadcasting and press media also present programmes and materials in such a distorted way to attribute all Soviet atrocities of killing, kidnapping sabotage, terror, harassment of the people and distructions to the freedom fighters and absolve the Soviets and their puppet Khalq/Parcham regime from all these crimes committed in Af Afghanistan. The state controlled broadcasting and press media give false picture of social, historical, cultural, political, economic and religious background of Afghan society and spread disinformation about the war of liberation, mujahideen, refugees, and national and international political developments related to the Afghanistan issue. The Soviet media strive to show to the Afghans and outside world that "the Soviet invasion is a benevolent assistance of an enlightened neighbour against a limited unpopular rea reaction by a group of landlords, reactionary mullahs, pirs, and thieves, instigated and directed by imperialist, chauvinist and reactionary circles against a popular and revolutionary regime in Afghanistan".

NEED FOR COUNTERACTION:

The media of the Afghan resistance has mainly focussed attention on the coverage of fighting inside the country. In contrast to the gigantic propaganda compaign being waged by the Soviet and their underlings for distorting every aspect of the Afghan life, the present efforts of th freedom fighters to counter this propaganda assault effectively seem insufficient, often redundant and sometimes polemic among themselves. On the other hand the freedom fighters have been dependent upon word of mouth to carry their message. Virtually the only publications, available to the people inside Afghanistan and outside which tell the other side of the conflict, are a scattered assortment of a definite outlook that are stronger on rhetorical emphasis on a specific political view and leadership than on facts at a national. level.

The Soviets are afraid of the pen which they often consider stronger than the gun. It was the main reason that the education elite, who could respond to the communist dectatorship effectively, were the first target of the Sovietbacked communist regime after it came to power in the 1978 coup. By the admission of Hafizullah Amin himself, "12,000 anti-communist intellectuals and professionals were executed during Taraki's reign." Undoubtedly all these executions are being instigated by KGB agents in the guise of diplomats and advisers to the communist government. In their person the Afghan have 
lost and are losing the cream of their socciety. Still some educated Afghans are in prisons and alarge number of them fled to the neighbouring countries. The majority of these thousands of highly educated Afghans-specialists in civilian and military fields-have come in the hope to stay and fight with their minds and pens against the invaders. This most important segment was not properly accomodated to participate actively in then main stream of their Jehad. As a result many of them had to leave for other countries. The majority of them now are of no practical use to their national cause and this Afghan brain-drain has had an undesirable impact on present resistance movement.

\section{WUFA:}

Realising the shortcomings in systematic counter propaganda inside Afghanistan, a few Afghan professionals and writers came together and established a non-partisan Writers Union of Free Afghanistan to render possible services to their national cause with their pens. The main objectives of WUFA for this paramount national cause are:

- To concentrate mainly on inside Afghanistan at national level,

- To write pamphlets to counter the communist pamphlets,

- To write different materials of practical use and interest for youth, educated elite and other sectors about the perverse effects of the Soviet system on the Afghan life, indoctrination, tricky tactics of divide an rule, sovietisation and russification, terror, atrocities etc. To this end WUFA will choose those wroks for publication, which are produced by qualified Afghans and freedom-loving scholars. In all such publications of factual nature, truth and accuracy will be stressed over polemics and dissagreement among the freedom-fighters.

- To translate selectively useful works on the Soviet Union and Afghanistan into Pashto, Dari, Turkic, Nuristani, Baluchi, Hazaragi, Dardic and other Afghan languages, Works in large volumes are condensed to make them portable and of interest to the Afghan readers iniside.

- To translate into major foreing languages authentic materials produced by Afghans on different aspects of the Afghan crisis in particular and Afghan society in general.

- To publish two Journals-one in English and other in Pashto/Dari, of comprehensive articles on the situation in Afghanistan.

All members of WUFA are fully aware of the magnitude of th task of countering the colossal propaganda machine of the Soviet regime that spends billions of roubles on this and thrives on it. This gignatic machine has all facilities at its disposal for spreading propaganda all over the world. Thus, we would be living in a foolparadise, if we, the uprooted refugees without 
any financial support, claim that WUFA will be able to meet such a propaganda assault satisfactorily.

There are several alternatives for educated Afghans now. Either they sit all silent and look at the bloody drama in their homeland as mere spectators, or serve and earn their liverlihood, or take refuge in foreign lands, or contribute by the pen to the war fought by the mujahideen with their guns.

The members of WUFA have chosen the last alternative in the hope that Afghans and other freedom-loving scholars and friends will not leave us alone in this most difficult task. We are sure that you will extend all possible help to WUFA-financial, scholarly works and others of which this organization feels itself in desperate need.

Last but not least, WUFA thanks the brotherly peoples and governments of Pakistan and Iran who have provided all possible facilities to the Afghan refugees in their countries on humanitarian basis. This brotherly help stems from the historical, religious and cultural bonds of these three brotherly Muslim nations. We are certain that the grateful Afghan will not forget their humanitarian support in this crucial period of Afghan history. 


\title{
SOVIET MILITARY TACTICS IN AFGHANISTAN
}

\author{
by
}

Major Nasrullah Safi

The Soviets place great importance on China and India for their decisive role in the worldwide communist revolution under Moscow's leadership. The Soviet military strategists never conceal that domination over the high seas ultimately leads to the sway over South Asia and the world at large. For this purpose Afghanistan has been considered a significant route to the warm waters. The arms race and the hectic struggle between East and West for strategic positions in Middle East and South Asia accelerated the Soviet ambition to move into Afghanistan.

Since the formation of People Democratic Party of Afghanistan (PDPA) 1965, the Soviets laid the foundation in Afghan military institutions for their thrust to the south. Meanwhile the Soviets were also aware of the fact that the PDPA, having no roots in the traditional Muslim Afghan society, would not be competent enough to sustain political power in face of the uprising of the freedom - loving Afghans. In such circumstance the Soviets would have no alternative but direct intervention in Afghanistan. Right from the beginning the communist ideologists often insisted in their propaganda literature that "the Soviet Union, the land of proletariats, revolutionaries, progress and peace, has never left and shall never leave her communist allies and friendly regimes alone to be attacked and toppled by the reactionary and imperialist powers". The Soviet ideologues, teachers in military academies in USSR and clandestine KGB contacts convinced some of the young officers, trained in the socialist bloc, as well as PDPA members to ask for Soviet military help whenever resistance in Afghanistan against their political power got a strong momentum.

After the Soviet backed coup in April 1978, the xenophobic Afghans started countrywide spontaneous resistance against communist ideology and the Khalq and Parcham factions which had long been known to Afghans as 
Russian proxies. Five thousand Soviet advisers were immediately rushed to Afghanistan to help the installed regime in various military and civilian fields. Upon their arrival the majority of the advisers were heavily concentrated in all Afghan military organs, AKSA (the then Intelligence Service) and the police forces. The advisers soon realized that the overwhelming majority of non-party Afghan officers were sympathetic to the cause of the Mujahideen and were opposed to the communist government. On the advisers' instigation, an era of Red Terror in the Afghan Army started. During the purge a large number of Afglian officers were arrested and many non-party officers in different garrisons were killed in abortive revolts against the communist regime. As a result, summary execution, agonies in torture cells, dismissal, demotion and defection became the daily fate of the Afghan officer corps.

Crushıng blows by the Mujahideen, nonconscription from the liberated areas and anti-regime activities of nonparty officers were the main causes of Soviet advisers' fear that the pro-Moscow regime in Afghanistan would fall soon. The advisers now came out in the open to plan to weaken the Afghan Army as soon as possible and pave the way for an immediate invasion of Afghanistan. For instance, contrary to accepted military tactics, the advisers were mobilising the Afghan contingents just for offensive sake. But they had not been trained for counter - insurgency nor were the Afghan officers told how to strengthen their positions in the captured areas. Whenever the Afghan contingents captured an area, the Afghan officers were immdediately ordered by the Soviet advisers to retreat to their former stations. The Mujahideen often trapped the retreating Afghan contingents and many of them were either killed or captured along with their arms and ammunitions. General Daud, the then corps commander of the Kabul garrison, protested against the Soviet tactics, but the same afternoon he was found dead in his office.

When the Afghan Army became too weak to defend itself against the Mujahideen in fortified garrisons, the Soviet advisers tried to persuade first Taraki and then Amin to invite the Red Army to intervene. At this time the advisers pretended that this proposal was based on the principles of socialist internationalism and came from sympathy for the Khalqi regime. But the Khalqi regime was not willing to accept advisers' proposals to invite the Red Army.

In the beginning the Jehad against the Afghan communist regime was spontaneous. The majority of the Mujahideen had no arms and the rest were fighting with outmoded arms and ammunition. They were not well organized and.their tactics of guerrilla warfare were extremely traditional. However, the casulties of the Khalq regime were much higher than they 
should have been. Within one year of the uprising the Mujahideen had inflicted heavy casualties and destroyed or damaged 800-900 tanks and armoured vehicles.

According to reliable sources, the Soviets had fixed the time for the invasion as June 1979. In this month the airborne forces in Ferghana (Tajekistan- were fully alerted for operation and the Ferghana officers' corps had been asked to send their families home. Due to some political hitches in Afghanistan the military operation was delayed. The main reason was that in comparison with the Parchamis the Khalqi officers were in majority in the Afghan Army. The Soviets were reluctant to invade Afghanistan and simultaneously face at official level Khalqi resistance and the Mujahideen at the national level. The age-old Russian scenario of Divide and Rule was the only solution. The Soviet advisers, diplomats and KGB actively tried to create a rift and enmity between Taraki, the Omniscient Master and Amin, the Loyal Disciple! Very soon the Soviets had Taraki murdered and Amin, the killer, was isolated to the extent that even the loyal Khalqi officers, who respected Amin as a contact between the party and army, were turned against him;

A new batch of military advisers, under the pretext of stopping widespread resistance movement against the Khalqi regime, arrived on November 3, 1979. The main body of occupation forces was flown to Kabul along * with heavy arms and ammunitions on December 25. On 27 December 1979, Red Army, rolling down the highway from the north, reached Kabul and at once all of the strategic positions were occupied On the same night the Soviet commando force stormed Amin's residence at Tajbeg where he was killed, and after four days Karmal was flown to Kabul from Tashkent to be installed as president.

The Soviets had thought that Amin's downfall, release of some remaining political prisoners and mighty show of tanks, armoured vehicles, airplanes and sophsiticated weapons would induce the Afghans into accepting the Karmal regime and surrendering unconditionally to the Soviet might.

A complete power transfer from the Afghan officers (specially the Khalqis) to the Russian advisers was a tricky process. After the invasion, Soviet advisers in Afghanistan were recalled to the Soviet Union. The main reason was that the Afghan officers treated them as equals and regarded their services in Afghanistan as a help based on the principles of socialist internationalism only. But in the second phase, December 1979, there was a fear on the Soviets' part that the Khalqi officers would disobey the old advisers, the Soviet military leadership had no alternative except to replace them with new advisers who, rather than international comrades in arms, were strict 
authoritarian masters dealing harshly with the Afghan officers. The new advisersstarted to take greater charge of Afghan military affairs by appointing Parchamis and Parcham sympathisers to commanding posts. The then defence minister General Mohammad Rafi was told to order these newly appointed officers to get the approval of the Soviet advisers for all military transactions. The notice read "The Soviet advisers have been assigned the task to coordinate the Afghan and the limited friendly contingents on the Soviet pattern to imbue the Afghan army with the long revolutionary experiences of the Red Army". This meant the Soviet advisers were the real commanders of the military operations designed by Moscow.

In the cold winter of 1980 , while the Mujahideen commanders were busy reorganizing and equipping their resistance groups to deal with the new type of Russian assaults, the Soviet generals transferred their forces to the most strategic areas for spring offensives. In the spring, the joint Soviet/Karmal forces launched attacks but due to strong resistance by the Mujahideen, the Afghan army suffered heavy casualties in many areas. The Soviet military leadership was forced to rethink over the disastrous consequences of the imposed war.

In joint offensives the Karmal contingents served as the vanguard, and played the major fighting role at the front. The Soviet Army cften remained in the rear or on the flanks of the battle-field to secure the offensive forces and block the routes which the Mujahideen used for their tactical retreat. Besides minimising Red Army casualties, the advisers also wanted to keep an eye on the Karmal soldiers to prevent defection to the Mujahideen.

Later, the Soviets changed plans for a swift victory into a protracted warfare doctrine. They wanted to leave the Mujahideen no alternative except unconditional surrender to the invaders. They calculated that it was the only way to achieve total victory over the tenacious resistance. They were not aware, however, that the Afghans had already prepared themselves for a prolonged war. As part of this, Soviet policy was divided into two sectors. In the occupied areas the process of military, political, economic, religious, social and cultural Sovietisation has been accelerated. In the liberated regions the villages are sometimes suddenly attacked and the dwellers slaughtered, the shelters demolished, the harvest burnt, the economic resources destroyed, the strategic localities depopulated etc. These brutal tactics were used against the Muslims of Central Asia. By repeating them in Afghanistan the Soviets want to induce the population either to accept the rule of communist government or to emigrate to Pakistan or Iran. (In the next article the depopulation policy of the Soviets will be discussed in detail).

It has been an unchanging Soviet tactic to place the target area under heavy 
bombardment before the actual operation starts. In these offensives the Soviet bring into action the air force and artillery, and sometimes mustard gas is also used. During the operation mobile groups spread over the area, saboteurs penetrate deep into the Mujahideen strongholds and some groups ambush the Mujahideen, moving along their paths. The same tactics are used in all military operations with only some slight variations for different regions.

\section{MISTAKES AND DIFFICULTIES}

It is well known that the Soviets have turned Afghanistan into a practice ground for experimentation with their sophisticated arms and ammunitions. These are used against defenseless Afghans. In this war fought in mountainous terrain, the Soviets, encircled by masses of resistants, are striving to adopt methods of mobilisation and administration of a large number of the contingents which have been brought to fight against guerrilla warfare.

Soviet marshals, experienced from the Second World War, face many problems from their lower-ranking officers who have no actual experience of warfare. Although the top leadership has electronic and automotic devices and equipment at its disposal to get the joint forces efficiently organised to inflict heavy casualties on the Mujahideen, it remains in fear of attack by the Mujahideen. This is one of the main reasons that the Soviet military leaders have not been able to eradicate the impediment to victory. Here their mistakes and impendiments are enumerated-

a. The Soviet military think tanks had planned all their warfare tactics for an organized war against regular NATO forces in the European theater. But the mountainous terrain of Afghanistan calls for anti-guerilla warfare. By keeping the Afghan guerillas under heavy pressure the Soviets military planners concentrated on the centre and flanks of their forces to strike deep at the defensive lines of the resistance to make headway for their advance. At the first stage the air force, artillery etc. were brought into action and then the land force were ordered to invade. During the 1979 invasion, the land forces often met with fierce resistance which forced them to retreat to temporary or permanent bases, sometimes with heavy casualties and losses. The guerillas hid during the heavy bombardments and suffered few casualties, contrary to Russian expectations. But the Afghans had no systematic defensive lines to operate from, on the other hand the freedom fighters acted in small dispersed groups. Thus, the Soviets had to modify their ineffective tactic of heavy fire from far away and move in closer for more direct contact with the Mujahideen. Though the Soviets had used this tactic in World War II against the German forces 
in the European plain areas, but mountainous Afghanistan differs greatly from the European areas. Now the Soviets bring armoured forces and heavy aritllery close to the Afghans strongholds to inflict casualties upon the resistants with the help of land and airforces. This tactic has also achieved no effective results. In many places the Afghan guerillas were able to raid closely guarded armouries and capture the weapons inside. The direct or close operations entail the danger of siege, destruction, losses and capture. In this respect the military pundits endeavoured to solve these problems. Their current operations indicate that the Soviets rely heavily on the MI-24 helicopter gunship, the only effective operational weapon against the fighters, who are really defenseless against it.

b. In the beginning the Soviets used the tactic of landing airborne contingents in regular warfare in which, according to their tactics they are capable to carry on effective fighting either for 3 to 5 days in maximum. But in the mountainous terrain of Afghanistan it became extremely difficult to operate because the few routes in the areas were usually blocked by the Mujahideen in wartime. After some disastrous casualties and losses the Russians were forced to rethink their airborne tactics and reduce them to the minimum.

Now the accumulated experiences of the Soviets induce them to use three different tactics airborne landings, saboteurs, and spreading the mobile contingents to destroy the Mujahideen strongholds. Sometimes these tactics are used simultaneously in mixed form.

c. During their operations the Soviets base these offensive contingents in strategic spots for ambush, and spread the mobile groups to capture the gurrillas along with their arms and ammunition. In some operations, with the help of local informers and planted spies, they succeed. But generally the Afghan guerrillas, with minute knowledge of their native area, have the ability to trap the Soviet mobile groups.

d. The mountainous areas in Afghanistan have deep gorges, and narrow passes with only a few beaten tracks. In such places the Soviets have a difficult choice. The terrain can not accommodate a large operational force and on the other hand a small force risks attack by guerrillas experienced in the area. In the beginning of the war it was the fear of extermination which made the Soviets send large contingents to these inhospitable areas. It was also difficult to direct such a large offensive force in the battle field. To reduce the casualty rate, the Soviets began to send their offensive forces toward the target in several columns, spaced apart.

The Afghan guerrillas, experienced in hit and run tactics, besieged the 
enemy forces in narrow passes, causing great disasters to the joint Soviet/ Karmal army. The battle plan was later modified to draw the Mujahideen from the mountains to the plains where their forces have the ability to manoeuver. Despite this modifications the Soviet/Karmal joint forces were still unable to set up bases. They remained on the defensive in the face of hit and run guerrilla attacks in the valleys too.

To reduce their casualties the Soviets have been increasing their clandestine contacts with dissidents in different areas. These agents facilitate Soviet offensives against Mujahideen strongholds.

e. The use of artillery and the air force, with the exception of helicopter gunships, is not very effective in mountationous areas. The Mujahideen are divided into small mobile groups without permanent bases. Thus, it is difficult for the Russians to first discern and then strike their stations. This is the main reason the Soviets desperately pound populated villages or towns and sometimes even deserted areas.

f. Relative to their huge war expenses, the Soviet invaders have achieved little success against the Afghan guerrillas. Russian warfare tactics are to moblize one or two contingents to strike at a 6 hectare area. They bring into action 18 to 36 heavy cannon which spend from 3600 to 7200 shells and Dashaka bullets and AK 47 catridges in the whole operation are numerous. For instance, if there is a group of 20 guerrillas in that 6 hectare area which sustains $20 \%$ casualities, this is only 4 persons. If the group has 30 guerrilas and 6 to 9 persons are killed, despite this high percentage of casualties the remaining guerrillas will still be able to fight effectively. But experience in the war has proved that the Mujahideen sustain very few casualities. The Mujahideen have learned to avoid unnecessary losses by splitting into very small groups of 3 to 4 persons to operate at a distance from one another. To attack such a small group the expenses of the enemy are quite large.

In some areas the Mujahideen have anti-aircraft guns. Soviets pilots, aware of this, strike only from a high altitude without any effective results.

g. In the beginning Soviet supplies were transported in large convoys with air protection. The Mujahideen were mobile enough to destroy armoured vehicles and tanks on the roads and capture large quantities of supplies along with sufficient arms and ammmunition. A great number of the military guards were killed. Due to these losses, especially when large convoys travelled to distant parts of the country, this method was progressively abandoned in favour of transporting supplies by air, which is very expensive.

To protect these smaller convoys, the Soviets set up small posts of joint Soviet/Karmal forces at strategic points of the highways. These also 
Nasrullah Safi

yielded no satisfactory results. They failed to stand up to guerrilla hit and run raids.

The Soviets still do not have full control of the supply routes. In spite of the fact that the Kabul/Sher Khan highway was patrolled and protected by the Soviets themselves, within only two months, March and April, 1981, the Mujahideen destroyed 80 tanks and 120 armoured vehicles on this strategic and most important supply route.

\section{CONCOLUSION}

1) The Soviets had a preconceived plan for the occupation of Afghanistan. In this respect their futile justification is of no help to excuse them of their naked aggression.

2) They had miscalculated the strong resistance from the freedom-loving Afghans and the odds which they would face.

3) They were determined to crush the resistance before the world condemned their act of aggression. But the Afghan resistance, despite many difficulties, proved that a nation committed to safeguared its faith, liberty and freedom, could resist the reputedly formidably Red Army longer than imagined.

4) This is a protracted war and the Afghans are fully psychologically prepared to continue it for many years.

5) The Afghans have to fight against the Soviets in the battlefield as well as on political, diplomatic, social, religious and cultural fronts.

6) The aggressors confront many difficulties to extricate themselves from the quagmire of gurrilla warfare. The desperate invaders often resort to clandestine contacts with dissidents, massacring innocent non-combatants and the destruction of civilian villages and towns. 


\title{
UNITY IS THE REMEDY
}

\author{
by
}

A. Rasul Amin

After a long six year period the entire national and international process related to the Afghanistan issue has become clear. This long practical experience has helped the Afghans percieve who their true friends and enemies are and estimate their strength and that of their adversaries. But at this crucial juncture all concerned Afghans are worried about the disarray in the rank and file of their political parties and some have corectly realised that it could require the influence of brotherly Muslim and other friendly countries to bring a unified and coordinated political plateform and military command to the faction-stricken parties and organizations.

Some might ask why others should take the responsibility of unification and coordination, and not the Afghans themselves? As a matter of fact it. would be hard to draw a definite line of demarcation between the interests of interdependent world wide states which face the same peril of Soviet domination. The current formidable Afghan resistance is not only a sacrifice for their liberation, but also a fight to defend the faith, liberty, sovereignty, economic, political, military and strategic interests of the neighbouring and regional states as well as of the world at large. Thus, in this hour of national tragedy they have full right to request the neighbouring, regional, Muslim, non-aligned and free world countries to stand united behind the Afghan cause and not let the champions of freedom and liberty crumble before the Soviet military machine.

\section{THE WARRING PARTIES:}

There are only two warring parties involved in the political arena, a super power and the victimised inhabitants of Afghanistan. All those with intimate knowledge of historical, functional and ideological background of the 
Khalq/Parcham factions give them no greater importance than two dummies in the Soviet show case to be used in a succeeding move. Their masters were already aware of complete non-existance of the proletariat class in traditional Afghan society. This was the main reason that the Soviets concentrated on the Afghan Army, using it as an operational force for their expansion designs. By an established tradition since Ahmad Shah Durrani (1747) the rural Pashtun tribes had been the main source of officer corps. At the first move in April, 1978, the majority of the Khalqi officers, coming from the Pashtun communities who got indoctrination and brain-washing in the Soviet Union and other satellite socialist countries, were used along with Soviet military advisers against the Daud regime. Immediately five thousand Soviet personnel (some of them KGB in disguise) arrived to help the so called civilian Khalqi regime in all civil and military fields. It was the first move to consolidate Suviet control over the installed Khalqis through trained Soviet agents.

After the second move, on December 24, 1979, the Soviet oligarchy ordered the contingents to move into Afghanistan to install the Parcham faction and take complete political power into their own hands.

Since April 1978, political developments in Afghanistan have verified that the Afghan tragedy is due to the Soviet Union. In this respect different scholars have traced out different causes of invasion. According to their theses the invasion was motivated by desires for: spreading Soviet - style communism; access to warm water ports; spring board to the Oil-rich Gulf states; Afghanistan's strategic postion; great enticement for Afghan minerals; fear of major change in Daud's policy; security of the Soviet Central Asian Republics; preventing reawakening of the Muslims in Central Asia; saving the pro-Moscow regime in Afghanistan; encirclement of China;regional and international development; etc.

Scholars belonging to different schools of thought have documented their theses, but it was not a single cause, but complex ones that have worked together to tempt the Soviets to invade an independent and non-aligned neighbouring Afghanistan. For the last seven years the invaders have been changing their political and military tactics according to different situations in various parts of the country to extend their occupation to the liberated areas. For this purpose they have divided Afghanistan into military and administrative zones. In general, all their tactics in these zones are based on double talk policy peace and terror, defence and offensive, security and brutality, temptation and entrapment and above all disinformation about all aspects of the Afghanistan issue. In some places clandestine contacts have been established with some of the local residents, tempting them with 
material gains.

In other areas the local commanders are induced to agree on temporary truces. But the strategic areas of Afghanistan are being kept under simulteneous heavy bombardment to the point of destruction and depopulation. Spies, informants, saboteurs and subversive elements infiltrate to create rifts, suspicions, rivalries, enmity and infighting in the ranks of the freedom fighters. The Soviets spread disinformation against the Mujahideen and refugees. In applying these tactics the real objectives of the invaders are to defeat the resistance first and then, in the second phase, completely impose Soviet - style communism on the traditional Afghan society. The constant indiscriminate bombing of strongholds of the Mujahideen is to crush the resistance and demoralise the people in general. Due to such brutalities the inhabitants of a given strategic locality are compelled either, to move to other safer areas, to surrender to Karmal regime or to emigrate to Pakistan or Iran. The invaders wish to put as much pressure as possible on Pakistan's meager economic resources and consequently to creat social and political problems among the refugees and locals.

Moreover, an overall campaign in educational, cultural, social, political, economic, military and religious institutions has been intensified to accelerate the process of Sovietisation and Russification in the occupied areas. The ${ }^{\prime}$ Soviets have concentrated on the Afghan youths. Every year thousands of students from the elementary schools up to the university levels are sent to the Soviet Union and other satellite countries where they are indoctrinated and moulded for the services of Soviet-style communism.

They are being brain washed of their Islamic faith and feelings of Afghan patriotism. At a young age, they are turned into robot - like cogs for the administration of the alien masters. Besides them, the Soviets have also started extensive programmes to send delegates from all walks of life to the Central Asian Republics, just to demonstrate selected show cases of the progress of communism and the leniency of the Soviet regime for Islam and Muslim communities. In short, the Soviets are gradually attaching all Afghan civilian and military institutions to the USSR and other satellities.

It is an inequitable war materially. Soviet Russia is the leading super power of the communist bloc, and enjoys the full subservient support of other communist parties, some non-aligned and Muslim countries. It has a large standing army, stolen sophisticated warfare technology and strictly centralized economic and political sstitutions with a colossal propaganda machine. In addition, the intruders run the Afghan civil and military personnel, the underling party members of PDPA, KHAD (Afghan Intelligence 
Service), the hired militia, the armaments (purchased by international hard currency), and other state organs. However the Afghans have a moral superiority for having rejected communist ideology. Throughout their history, the Afghans have never submitted to any foreign invader. As true sons of their fathers the Afghans are religiously and traditionally bound to sacrifice themselves for the glory of God and liberation of the Mother-land

The Afghans have not invaded the Soviet Union, rather they have been victimized in their own ancestral land. By all human standards the Afghans have waged a just war against atheism, aggression, brutality, and atrocities of the communist regime. In this respect the world-wide moral support of freedom - loving peoples is an encouraging factor to sustain the fighting spirit of the Afghans.

\section{A HOUSE DIVIDED:}

Since April, 1978, the Communist coup and the Soviet invasion of 24th December 1979, forced the Afghans to take refuge, as members of a Muslim nation on the soil of neigh bouring brotherly nations - Pakistan and Iran, but in a strict sence it was not a refuge to a person, a group or party. Right from the beginning, all the Afghans inside and outside expected that the brotherly neighbouring Muslim and friendly countries would bring them under a unified individual or collective leadership. But instead the Afghans found themselves in a House Divided. It has turned a compact commonwealth of a nation into fragmented factions. In order to give strong resistance to the aggressors the Mujahideen were in dire need of help from any quarter. They were left no other alternative except to accept the reality of division to obtain required supplies for the Jehad.

All the Afghans, including party leaders and commanders, know that unity strengthens the resistance and disunity paves the way for a complete defeat. Then why haven't they unified or coordinated their rank and file? It could be only due to human greed for personal gain. For instance if a person enjoys all sorts of political and social privileges, psychological satisfaction and unaccountable financial assets, will such a person give up his personal gains for a unity in which he might see himself either reduced to a secondary position or a loser? Never, except that one who willingly surrenders his personal interests for a broad national cause. It is very unfortunate to say that the prevailing disunity has caused several undesirable effects: 


\section{HARMFUL EFFECTS OF THE DISARRAY:}

1) Despite the fact that Islam binds the Afghans together, in sociological terms, Afghanistan's social structure is triba! and semi-tribal with many political and local rivalries and feuds. From the facts available from inside the country it appears that if one group receives help from a resistance party, the rival groups in the area attach themselves to other parties. A power struggle starts which sometimes leads to infighting. The Mujahideen often lose experienced fighters. In such circumstances the KGB and KHAD take opportunity to catch the fish in the muddy water. This tragic process of infighting will make the Afghan fighting force too weak to effectively resist the occupation forces.

2) In many parts of the country the rival groups become close by fighting against the common enemy. But sometimes dominant groups in some areas behave in arrogant, domineering and harsh ways towards weaker rivals and the civilian population. The dominated rivals either must fight, or flee to other areas for safely, or surrender to the Karmal regime just to take revenge. Similarly, some local people are also driven to join the government paid militia.

3) It is easy for KHAD to plant trained spies or hired agents in the factionstricken areas to convert the dissident elements to the regime, intensify the already existing conflicts, spread disinfornation about the Mujahidden, report on all activities and pinpoint the strongholds of the resistance. Moreover, now and then dissidents are induced to desert the dominant rivals in the battlefields to the joint Soviet and Karmal forces. The Soviets want to help and capture the Mujahideen alive or inflict heavy casualties upon them.

4) In absence of a unified and coordinated political and military command, some of the local commanders judge all social, political and military questions on their personal likes and dislikes. This state of affairs in some areas creates dissidence and also keeps some influential and useful figures away from the mainstream of Jehad.

5) Internal conflicts and rivalries for increasing sphere of influence pave the way for businesmen, robbers, and killers who can easily attach themselves to one of the parties. These undesirable: elements misuse the facilities of Jehad either for their personal profit, to further their age- old family feuds or for robberies and harassment.It is these disreputable persons who are the real cause of hatred against the Mujahideen and provide documents for the Soviet propaganda machine against the resistance. 
6) Sine the installation of the communist regime in Afghanistan thousands of highly educated Afghans, specialists in civilian and military fields, have come to Pakistan and Iran in the hope of actively participating in their Jehad against the occupiers. Many of them were determined to stay and get a chance to render their services to the cause of their homeland. Unfortunately this segment was not properly accommodated to fight with their minds and pens. As a result, their financially and political insecure and embarrassing situations forced many of them to leave for other countries. They now have no practical use for the resistance. This Afghan brain-drain has negatively affected the resistance movement and the remaining few still face the same problem of not being properly accommodated to contribute their know-how to the national cause. It is feared if the remaining few do not get a chance to participate in the main stream, some of the frustrated ones might follow the foot-steps of the other emigres.

7) At the national and international level the Soviet propaganda machine continuously distorts the Afghanistan issue as a struggle between" progressive and reactionary classess". Little attention has been paid to countering Soviet propaganda inside and outside the country. If the one-sided propaganda goes on without check, in due course Afghan youths might yield to Soviet - style communism, Russian cultural imperialism would be a fait accompli, and the international community will gradually lose interest in the cause of disunited and factionridden Afghans.

\section{UNITY IS THE REMEDY:}

Despite the fact that the Afghan political parties and organisation have worked hard during the imposed war to sustain tough resistance in the battle fields, and that a large number of the Mujahideen have been martyred under their command, it will be very difficult for the Afghans to endure the concomitant agonies of disarry in rank and file, infighting socio-economic and psychological strain, and the great cruelties of the most brutal enemy ever known to them. Undoudtedly, terror and insecurity from the enemy's side and disorder in their own political bodies have a very disheartening impact on the morale of the Mujahideen and refugees alike. There are some who are in a quite baffled mood, seeing no light at the end of the tunnel.

In this crucial wartime it is very hard to separate the political and military aspects of the Afghan crisis. Both play the role of cause and effect. If a unified political plateform brings a coordinated command, thus, on its part 
the coordinated military command also gives greater strength to the political plateform on the national and international level and as a result both of them ultimately lead the resistance to the final destiny-the liberation of Afghanistan.

For this sacred objective, all the Mujahideen, refugees, and the silent resistants inside the country earnestly desire not less than a unified or coordinated political and military command under an individual or collective leadership to get them organised and to attract decisive international support for their cause. As a first step it is imperative for the unified or coordinated leadership to analyse objectively, in the light of regional and international political developments, the Soviet expansionist policy, the causes of conflict, the crucial situation inside the country, and the forthcoming concurrent political, economic and social effects of the crisis on the neighbouring countries. The leadership must categorise enemies and friends in the broad perspective of national interest, not on the basis of their personal likes and dislikes. And in this respect the good offices and influence of brotherly Muslim and friendly countries are needed in the utmost. 



\title{
SOVIET AGGRESSION OF AFGHANISTAN
}

\author{
by
}

Dr. Z.A. Mumtaz.

In less than one decade of the seventies there were four consecutive coups in a land which had enjoyed a relatively longer period of peace and tranquility all over the country. Daud dethroned King Zahir Shah in 1973, in a bloodless court conspiracy and in April 1978; this pioneer of good neighbourly relations with the Soviet and succeeding coups in Afghanistan; was killed along with all his family in the Soviet - backed military takeover of Khalq/Parcham factions. For the first time in Afghan history, Taraki, the proMoscow communist, initiated an era of Red Terror in the hope of bringing the freedom loving Afghans under communist dictatorship. After the coup, the honeymoon between the Khalq and Parcham factions lasted for a short period. The Khalqis, having their stronghold in the Afghan army, expelled the Parchamis from important posts in civilian and military institutions. Karmal and some of his close comrades were exiled as ambassadors to various countries.

The Khalqi regime claimed that a coup by the Parchamis against the "Saur Revolution" had been discovered, and as a result many prominent Parchamis, such as Abdul Qadir, Sultan Ali Keshtmand, and others, were arrested, but not executed due to the Soviets succour. Karmal and other Parchamis ambassadors were declared involved in the coup and all of them were recalled by the Khalqi regime for "urgent consultation". Karmal and his colleagues refused to come. They were denounced as "fugitives in Western imperialist countries and looters of the money in their respective embassies". They were charged of "high treason: against the people and revolutionary regime and were to be punished by the people's court".

Meanwhile, the Soviet diplomatic and intelligence channels set Taraki" the Omniscientt Teacher" and Hafizullah Amin "the Most Loyal Pupil" against each other. In this staged drama the loyal pupil killed his omniscient teacher. 
But during this bloody change the Soviets did not say anything against Amin, rather it was declared an Afghan internal affairs. Apparently the Soviets kept their relations with Amin friendly and cordial but the high circle in the Kremlin was busy with the plot to kill him. The story of this plot is as follows:

The Politburo itself periodically sits down to ponder details of espionage, deceptions, and sometimes more sinister subterfuges. In the autumn of 1979 the Soviet rulers assembled to mediate upon a particularly delicate question. Should the KGB assassinate the president of Afghanistan, Hafizullah Amin, and replace him with a Soviet agent (Babrak Karmal)? After studying the plan, conceived by Andropov's underlings and approved by him, the Politburo voted da(yes).

The KGB chose a well qualified officer, Lieutenant Colonel Mikhail Talebov, to be the assessin. As a member of Directorate $S$, which illegally infiltrates disguised KGB officers and agents in to other nations, Talebov was highly versed in clandestine tradecraft and accustomed to perilous assignments. Having grown up among Muslims in the Soviet republic of Azerbaijan, on the Iranian border, he spoke Farsi as well as any Afghan. And with identification? papers forged by the KGB, he had lived several years in Kabul passing as a native Afghan.

Talebov entered Afghanistan in early Novermber 1979, posing as an Afghan chef; and through arrangements made by the KGB network in Kabul, he obtained a job as a cook at the presidential palace. In the palace kitchen the Lieutenant Colonel awaited his opportunity. Always he had with him a colourless, odourless poison brewed by the Technical Operations Directorate in Moscow specially for president Amin. And according to his reports to the Kabul Residency, at least twice he dropped poison in the fruit juice ordered by Amin.

However, while aware of Amin's fondness for fruit juice, the KGB did not appreciate how wary and wily he was. Fearful of poison, he always filled his glass with small portions of juice from many different containers. By mixing the juice he reduced the poison ingested from any batch to a non - fatal level and apparently did not even become ill, for there was no investigation of kitchen staff.

Dubious about whether Talebov would succeed in poisoning the president, Andropov and the Politburo ordered more forceful action. On the night of December 27, 1979, a KGB assassination team led by Colonel Bayerenov and backed by Soviet commandos, stormed the palace. In an upstairs salon they found Amin and killed him along with a lovely female companion. But the palace guards fought so ferociously that Colonel Bayernov dashed outside to 
call in reinforcements. Because the Soviet wanted no living witness to the assassination, the attacking troops were under order to allow no one to leave the palace alive, and in the darkness they shot their commander, mistaking him for an Afghan.

Ultimately, the Soviets did kill nearly everyone inside the palace. Among the few survivors was Lieutenant Colonel Talebov. Though no one had told him of the raid, and no one had told the raiders about him, he managed in the confusion of the slaughter to escape"1

Thus, the Soviets, the so called champions of coexistance, non-interference and good neighbourly relations, killed their own surrogate when they invaded the independent and nonaligned homeland of freedom - loving Muslim Afghans. At midnight on December 27, 1979, Karmal, the most loyal agent of the Soviets, was installed as successor to the Amin regime and the self-invited Russians took everything in their own hands.

\section{THE REIGN OF RED TERROR:}

The occupiers, using Nazi tactics, began to plunder villages and towns and kill innocent men, women, children and even infants in their cradles or in the arms of their loving mothers. The carnages of Keralah village in Kunar province, Chardeh in Nangarhar province, Pathkhwab and Mohammad Agha in Logar province, Stalif and Salang in Parwan province, Chardarah in Kunduz, Nanai and Rowza in Ghazni, Gushkhana and Nagahan in Kandahar, Herat city and Bamian are a few examples of the Red Terror to be mentioned. The plunderers do not spare the national wealth of the victimised Afghans. They looted all the precious relics of the National Museum, all the gold reserves of $D a$ Afghanistan Bank (State Bank) and furniture at Dilkusha palace. The Red burglars stole all foreign - made radios, taperecorders, television sets, watches and other valuable commodities of Jamhoriat Market in Kabul and of Atta Sarai in Kandahar. Every day they send many stolen things across the Amu Darya (Oxus) to the Soviet Union, either to their families or to the state treasury.

The barbaric bambardments of the invasion forces have already destroyed sixty percent of the villages in the liberated areas and have demolished some large portions of towns and cities, including Kandahar and Herat. By this

1. Joh an Barron, K.G.B. TODAY PP. 15-16, Great Britain, 1984. 
savage policy the Soviets want to force the inhabitants of strategic localities to migrate to the neighbouring countries of Pakistan and Iran. Moreover, the majority of the people of these areas have been compelled to leave their homes and become internal emigrants. Their gunship helicopters and Mig bombers chase the guerilla and civilians alike all over the country. As a result one fourth of the population has moved to neighbouring countries and more than one million have been martyred.

According to my personal observation last December of many parts of Afghanistan in general and of Kandahar province in particular, most of economic, transportation, communication, electrical, industrial, agricultural, irrigation and educational systems have been either completely destroyed or put out of operation by the Soviet forces.

Government administration operated in shattered form and all educational institutions were almost without teaching staff, students or administrative personnel. For instance, before the coup, there were 1835 teachers in Kandahar province, but last December there were only 36 personnel on duty. There are only three schools functioning in the province with 76 students attending classes regularly. Many of these students have registered themselves just to avoid conscription for the dwindling Afghan Army. From 9069 administrative personnel of the province only 1062 were attending their respective offices. Similarly the Kajaki Project in Helmand province had shrunk to the extent that out of 1200 former functioning personnel only 13 persons had remained to attend their duties

By their age-old tradition the lively Afghans had full liberty to go out at night for all sorts of enjoyment. But for the last seven years the inhabitants of the occupied areas are under constant curfew from dust to dawn and during this suffocation period all of them have been deprived of the greatest natural right of liberty pleasure. The Soviets firmly believe in conditioning theory. The Soviet-controlled Kabul radio, television and other stations in provinces continuously remind the unfortunate residents to stay home every night during curfew times. This has conditioned the young generation to the extent that they have become quite unaware of evening pastimes which their elders enjoyed before the coup.

\section{UNEQUAL WAR:}

All the Afghans know the real strength of the faction-stricken Khalq/Parcham gang. There are many factions within each faction. Parcham is divided into two major groups, led by Babark Karmal and Sultan Ali Keshtmand. The former is called "Karmalove's European Parchamis" and the later is named 
"Aliyov's Afghan Parchamis". Khalq is also divided into three groups, led by Saleh Mohammad Zirai, Dastagir Panjshri and Gulab Zoi. Their groups are called"Disciplined" "Workers" and "Bandist" Khalqis respectively. The first group is a carbon copy of Parcham and the second one follows a mid-way policy, but Gulab Zoi's group is the one most hated by the Parchamis. Most of the Khalqis being purged from the party are denounced as undesirable "Bandists".

Internal conflict between Khalq and Parcham factions does not stem from any ideological, political and policy differences. Both of them are Soviet creatures, and since the formation of PDPA in 1965, both have done nothing except spreading Soviet-style communist ideology, spying on all groups and individuals in rural and urban areas and at last paving the way for the Soviet occupation of Afghanistan. From April 1978 till December 1979, the Soviet - backed Khalq faction was the dominant stratum, which enjoyed all political, economic, bureaucratic and social privileges in the country. All of a sudden the Red Army replaced the Khalqis by the rival Parchamis and deprived them of all privileges in one night. Today Parchamis are the most trusted agents of the occupiers and enjoy all the privileges in government and party hierarchy.

It is a war between a small nation and a super power. Afghanistan the highway of conquest, is situated in the heartland of Central Asia, and has often paid heavily for her geopolitical location. Many conquerors have passed over this cross road to and from the Indo-Pak subcontinent, Middle East and Central Asia. The very historical facts of this region tell us that any conqueror who has passed through the Hindukush and Khyber passes had ultimately reached the Panipat plains. Similarly the aggressors who have subdued the gate of India, either Kabul, Kandahar or Herat, have also conquered the capital of Indian Empire. It is for its strategic importance that the military strategists have denominated Afghanistan as "the highway of conquest" "cross road" "gate of India" and "springboard to the oilrich Gulf states".2

Certainly there is a great difference between the aggressor and aggressed in population, military strength, technological output and economic and political organization. The Soviet Union, being a super power, has acquired all sorts of material instruments for her war machine, which has been geared

2. Alama Iqbal, the philosopher poet of Pakistan, refers to the importance of Afghanistan in the following lines:

Asia is a constituent of water and mud.

The Afghan nation is the heart of this constituent.

With her fall Asia falls.

And with her stand Asia stands. 
towards world domination. On the other hand Afghans, the inhabitants of a small country, have neither large population nor sufficent military strength nor any cohesive political and economic organization to match the aggressive super power effectively. But the only factor, which has sustained their moral high for the last seven years, is that faithful and freedom loving Afghans fight for the glory of God and liberation of their motherland against the Godless communist ideology and intruders into their ancestral homeland.

Last year I myself saw the men and women in Arghandab district of Kandahar province, how firm and determind they were!

Here I wish to relate three examples in brief: An old man was going from village to village and telling the villagers:

"We are true belivers in God. He has ordered us to sacrifice ourselves for His Glory and the liberation of our homeland. The Russian tanks, gunship helicopters, bombers and fighters must not scare us. The Almighty tests us, whether we are ready for martyrdom or not. If we are ready, I assure you that no earthly power will be able to defeat us. If we are not ready for that highest bless I am sure we will lose our faith and our homeland to the infidles forever. The infidles have come to our doorsteps. Fight them to the last drop of your blood."

In a fierce fight between the Mujahideen and the Red Army, a Russian helicopter was shot down. A jubilant lady was running from house to house and was breaking the good news to every one inside the houses.

"These infidles always tell us that their helicopters are bullet proof and cannot be shot down. Look what big liars they are! I saw myself that their helicopter was hit by our Mujahideen gunners in the air. It smashed and fell on the ground burning. God is with them. Our brave Mujahideen are all capable of fighting against the infidles on land and in the air".

Although fight in Arghandab district left many dead bodies on the battlefield both on the Mujahideen and the enemy sides. In this ferocious fight an old widow also lost her only young son who was the dearest one in her life. Everyone in the village predicted that her son's death must cause her heart failure. The elders of the village started to deliberate upon three alternatives, whether to tell; her son was dead or captured by the enemy or had gone across the border. After a long discussion they agreed to take the dead body to his home. Men, women and children came in procession along with the dead body. Every one was paying heartfelt condolence to the shocked mother. The bereaved mother uttered nothing and she was gazing the dead body, covered with his blood, for one complete hour. It was a heart breaking scene. At last she recovered from the stunned state and said: 


\section{Soviet Aggression of Afghanistan}

"Thanks God that my son has not been killed for any indecent deed. He was a Mujahid and died a martyr's death. My son has sacrificed himself for the Glory of God and his homeland. It is a sin if I weep over the dead body of my martyr son".

\section{UNITY BRINGS LIBERTY:}

Since the imposition of Red Terfor, all the Afghans, irrespective of their sects, tribes, clans, lineages and localities, have been fighting against the most brutal, inhuman enemy ever known to the Afghans. In this unequal war of genocide, hundreds of thousand from all walks of life, are made orphans, widows, crippled, martyred, homeless, internal and external immigrants. Moreover, the Soviets are busily at work to brainwash the youths, making them communists and spies and introducing the immoral communistic life style, to Sovietise all aspects of life and destroy the very fabric of social structure of the Afghan society.

As their long range policy reveals, Soviets seem determined to stay in Afghanistan till their puppet regime is consolidated. To achieve this goal they have to exploit and utilise all means at their disposal,increasing terror, torture and bombardment of strategic areas to demoralise the resistance and force them to submit. The Soviets know that there are some greedy elements who can be tempted to work for money only. Most of the Parchamis, Khalqis, militiamen, spies informants, personnel in civilian and military institutions, working for the consolidation of the communist regime, do not know the sinister aftermath of Marxism- Leninism in their homeland, but work for material gains only. This hated stratum gets money from the Soveits just to kill the Afghans and to sell their motherland, faith and even their soul to the occupiers.

The government and people of Pakistan have accommodated more than three million displaced Afghans on their soil on humanitarian basis. The angry Soviets have started air violation of Pakistan's territory and spread disinformation against the Afghan refugees and Mujahideen and put pressure on the government of Pakistan to begin direct negotiation with the Karmal regime and repatriate the refugees to the Soviets slaughter houses. There is a hectic struggle by the Soviets to undermine the correct policy of the present regime on the Afghanistan issue, as well as for the very integrity, solidarity and sovereignty of Pakistan. The Soviets try to avail themselves of the chance for a longer stay in Afghanistan in order to impose complete Sovietisation on the young generation in Afghanistan and wait for political change in Pakistan's attitude which they think might be for their benefit. 
There is country-wide national resistance against the invaders. And in this unequal war the Afghan nation has paid a very large price for their freedom, more than any nation in contemporary history. Worldwide public opinion also supports the just cause of the Afghans. Despite all this heroic resistance, sacrifices and international support the Afghans have not compelled the aggressors to sit down and negotiate with the Afghans for the withdrawal of occupation forces. The main cause of this tragedy is the prevailing disunity among the Mujahideen, which the enemies exploit for their own success.

If ever, there is a unified political plateform, coordination in the battle fields training of youth for guerrilla warfare, accommodation of all freedom fighters in their right places, and classification of friends and enemies, then the arrogant intruders would be forced to come to the negotiation table to discuss the withdrawal of their occupation forces. 


\title{
COORDINATION LEADS TO SUCCESS
}

\author{
by \\ D. M. Khalil
}

It has now been more than five years that the people and government of Pakistan have hosted about three million refugees on their soil. There has been no significant improvement in the efforts to help these three million refugees return to their homeland. Unfortunately for Afghans, inside and outside their country, the resistance political parties and organizations have not shown any willingness to form a united or even a coordinated political and military front to compel the Russians to withdraw their occupation forces. Despite the fact that the people of Afghanistan are good fighters and have the will to keep the resistance alive against the Soviet invaders, it will be very difficult for such faction- stricken Mujahideen to oust the occupiers from their country. There is little cohesion and solidarity among the fighting groups; moreover they lack social and political understanding of the wartime problems of Afghanistan. For example, when the Mujahideen liberate an area they neither strive to establish a unified local administration nor to help others liberate the areas still under the occupation of the communist regime. They just sit in their liberated localities and expect other fighters to liberate the occupied areas themselves. Such disunited operations based on ethnic and tribal grouping are not effective. All the Mujahideen and their sympathisers must open their eyes to the bitter reality that nothing can be acheived unless there is a unified political front and a coordinated military command.

The Mujahideen, inside Afghanistan, operate in groups directly under the command of their respective leaders across the border. But the field commanders in Afghanistan are free to make their own decisions and have the power to tax and retax the local population under their control, with or without the approval and knowledge of the leaders in Peshawar. Any action by the party leaders against the field commanders, to stop them from harassing the local population, would result in a shift of loyalties to another party whose leader would always welcome them. Bitterness is, thus,created among the rival parties 
and organizations.

Coordination among the Mujahideen is also important in relation to the various types of aid given by the Muslim, Western and other countries. . Today donor governments, agencies, institutions and persons are confused and they do not know whom to help. In comparison with the disorderly situation in Afghanistan, one can easily find in other liberation movements well organised political, military, economic, social and cultural unification and even orderly medical and agricultural programmes geared to protracted warfare. Today Afghanistanis is like a flash flood. It has the potential to destroy all if not properly harnessed, but also has the potential to produce good results if properly harnessed.

The Soviets have come to Afghanistan on the basis of a long term policy to stay, or at least to sovietize the Afghan people. They want to establish a status-quo. They want time to educate and indoctrinate the younger generation along communist lines, so that after a decade the Soviet will have dedicated surrogates working for their interests in Afghanistan. Even if the Soviets do not physically annex Afghanistan, they would like to annex it ideologically to the Soviet Union to ensure the maintenance of an underling communist regime in power in this strategic land. This can only be achieved by indoctrinating the young generation and for this they need time. It is imperative that the Russians be denied this objective.

The Russians are destroying the infrastructure of the areas under the control of the Mujahideen by forcing the local population either to migrate to Pakistan or go to the cities and areas under Russian control where they have access to basic amenities. In this way the rural population is driven out, thus, depriving the Mujahideen of their logistic support. On the other hand, the Afghan refugees are becoming the victims of dependency syndrome, being provided with foodstuff and looked after by the government of Pakistan, with international aid,. Conditions are becoming difficult for the Mujahideen since the rural population is thinning out. Fields have been destroyed by the Russians and there is also an acute shortage of medical care in the countryside. This shortage can be met by providing medical care to the local population inside Afghanistan. Any wounded Afghan male, female or child has to be carried to Pakistan and with them many family members come as well. If enough medical help is given inside,people with minor injuries can be treated locally, which will also reduce the influx across the Durand Line. The most important factor is food, since the rural areas are constantly bombed and the inhabitants are forced to abandon their agricultural activities and migrate to Pakistan. Food scarcity is felt in many places and this undesirable situation should also be loo- 


\section{Coordination Leads to Success}

ked into. There is acute need for food supplies in nearby areas and cash money for the remote areas where the price of local food is cheaper than the outlay for the transportation of extra food would be. Certainly the supply of medical care and food inside Afghanistan are most important factors in keeping the people in their localities. They can then not only be of great service for the Mujahideen, but also lessen Pakistani economic and social problems. Whenever the Russians intensify their bombings in strategic rural areas, thousands of victims pour into Pakistan, which eventually will increase the population of refugees to an enormous number. This again necessitates the forming of coordinated command and policy for the people inside the coun ry. The more refugees there are the more tension will build up between the locals and refugees on the one hand, among the different refugees groups and refugees.

Undoubtedly, there is a great amount of good-will between the refugees and the people of Pakistan. This has been achieved by the sincere efforts of the people and government of Pakistan. The refugees and Pakistanis must strive to maintain the existing good-will. 



\section{A MILLION DEATHS SINCE 1979: WHO CARES FOR AFGHANISTAN?}

by

Jamila Luijckx and Dr. G.J. Wennik

The Afghans are a poor, but dignified nation. Their independence is so dear to them that they have resisted a superpower that has occupied their country and employs the most terrifying arms of destruction. Many Afghans know from their history the invasion of the Mongolian hordes of Changiz Khan, who invaded their country and destroyed it in the thirteenth century. Its armies of invasion ruined the systmes of irrigation which changed fertile valleys into deserts. The centres of the rich Afghan culture were depopulated.

The Soviet Union, familiar of old with the way the Mongols wage war, uses, it appears, the same military methods in its military operations 700 years later. Tens of thousands of Afghans are tortured,and hundreds of them are executed daily. In all $1,000,000$ people have been killed since the 1979 invasion. Food production is destroyed on purpose; underground water systems, centuries old, are blown up and water wells poisoned. The crops in the fields are set on fire, cattle too fall victim to mines, bombings and chemical arms of the Soviets.

The intention is to isolate the resistants (the Mujahideen). The weapon of hunger is used by the cccupying force with subtle guile. Where resistance has been broken, and the population collaborates with the communist regime in Kabul, the farmers are provided with seed, fertilizers and tools. But areas that persist in their opposition are made to suffer. The villages are permanently covered by Russian helicopters that shoot rockets and drop mines, sometimes the boobytraps that cause frightful wounds, particularly with innocent children.

The occupying force uses a number of arms that do not kill but rather mutilate. Those who are wounded are a greater care for survivors than the 
dead, particularly when medical aid is lacking. In the end most of the wounded suffer complications and die anyway. According to French physicians in Afghanistan, three out of four wounded suffer this fate. In several places chemical weapons have been used.

After a struggle of more than 7 years, about half of the original population (15 or 16 million) are victims of the war, directly or indirectly: 1 million dead, 3 million refugees in Pakistan, $1 \frac{1}{2}$ million in Iran, 1 to 2 million who are on the run in Afghanistan.

\section{PESHAWAR:}

The refugees in Pakistan are doing well compared to the other groups. About 6,000 cross the border every month inspite of strict border control and the bombings in the areas. We saw 4 children in a shack behind the bazar of Peshawar. Two of them were tortured for carrying messages in Kabul for the resistance. A girl of 13 had been "selected" for a 10-years period in the Soviet Union after which she was to work for the new order in her country as a well trained communist.

They fled with their mother abroad, mostly on foot. The mother had to return to her sick busband in Kabul. They were looking for a reliable paid guide who might take her back across the border along hidden trails. The roads into Afghanistan have been close almost completely because the violence of the war has approached Pakistan all the time. She said good-bye to her children 4 times: the first 3 attempts failed. At the fourth attempt days follow full of anxiety for the children, waiting for the news that their mother has reached Kabul in safety. Two weeks later the news arrives that she has reached her sick husband.

There are tears in one of the camps where widows and children live, when they tell us about the terrorism in Afghanistan, about their husbands and children they lost, first to the violence in the villages, then to the terrible journey to Pakistan. They still suffer: even now children die of dysentery and small pox. They drop their veils and show their poorly healed wounds, mangy spots on their arms due to lack of vitamines, and heads full of lice. But they are happy to tell their experiences to a woman from outside the camp, who is willing to listen to. They are isolated, have little useful work and not leave the camp without the protection of the husbands they have lost.

In spite of their terrible fate, the Afghans are determined to regain their freedom. One should see this both as a Jehad against communism as well as a national resistance against the greatest tyranny which intends to destroy the infrastructure of the Afghan society. The Afghans face all sorts of odds 


\section{A Million Deaths Since 1979}

in order to restore their own way of life and national independence. The Afghans point out to Western visitors that it should not merely be a matter of Afghanistan itself but of all the whole free world. How can that West allow a whole nation to be killed slowly? If we want to prevent the Afghan disaster to grow in the next few years, the West will have to provide large scale assistance, food and medicines.

\section{AID:}

Recently the Dutch House of Commons have accepted a motion, there was one dissenting vote - to call on the government to provide such aid. But will this be realized? Most of the foundations in Holland, that work for the Third World, avoid the Afghan problem. If one examines the 1984 budget of the N.C.O. (the National Committee for Third World Affairs), it turns out that huge amounts of money are spent on institutions that are involved with the problems in South Africa and Central America; Afghanistan received $\mathcal{L} 5,650$, it means the Afghan receives little attention.

It is in Afghanistan itself that the greatest need exists for international aid. The refugees abroad are looked after, more or less, by Pakistan, Iran and the international community. If no help is offered in Afghanistan itself, the country will bleed to death quickly. Chanelling aid to the Afghans is not easy, because of the war, but it is still possible. Reliable ways have been found by foreign aid organizations, such as "Physicians without Borders". Large parts of Afghanistan (80\%) are under control of the resistance organizations that co-operate more successfully all the time. If the western democracies offer no help to the victims of this cruel war, they have abdicated from the knowledge what peace and freedom are really worth. 



\title{
A PROTRACTED WARFARE AHEAD
}

by

\author{
Mohammad Hakim Aryubi
}

Needless to say that the Russian aggression has brought not only implications for the future of Afghanistan but it has also the most serious geopolitical
situation in its trails for the region too.

While raising hullabaloo of foreign intereference in the internal affairs of military operations against the native Afghans. The Russian leaders are actually flouting the relevant resolutions of UN General Assembly, Islamic Conference and the Non- aligned Movement regarding the unconditional withdrawl of the Russian occupation forces from Afghanistan. And the Russian leaders have also launched propaganda compaign to deceive world public opinion. On the other hand, attempts are being made by the Russian leaders to dictate and impose a military solution on the freedom fighters. It national communist duty to sustain the most hated regime in Afghahistan by sheer force in flagrant violation of generally accepted norms of international leaders has caused tragic devastation illegal and brutal duty of the Russian have arrogated to themselves the right of Afghanistan. The Russian leaders and the fact remains that the Russian arrogan intervention in Afghanistan main obstacles on the way to the political solution and intrasigence are the The Russian leaders understand the language solution of the Afghanistan issue. Afghan Mujahideen must not allow the overall military favour of Russian intruders.

Thus, it would be indeed a misleading and even self defeating perception if the Afghan Mujahideen expect a speedy political settlement of the Afghanistan problem and ignore the military aspect of this vitally important issue,. In 


\section{Mohammad Hakim Arubi}

the prevailing state of affairs, the Afghan Mujahideen would be well advised to prepare themselves for a portracted warfare of national liberation, because the occupation for except the continuation of their armed struggle against importance of the future Fighters should not in any way lose sight of the time, advocate a political solutionent of the armed struggle and in the meandrawl of the Russian forcelution based on the total and unconditional with-

The current situation in accordance with the UN resolutions. must blead further in calls for a more combat readiness that the Russians adventure in the land Afghanistan and pay a high cost for their military of the Mujahideen to of tough fighters. It is imperative upon the leadership tists together to plan the highly qualified military experts and social scienand military fields. The strategy and tactics of the protracted war in social this protracted war who leadership should introduce the young Afghans to other social, economic should be well trained in querilla warfare and in all 


\section{PASHTUN TRIBES AND THE AFGHAN RESISTANCE:}

by

Hakim Taniwal and Ahmad Yusuf Nuristani

The Afghan resistance, against the Red Military Machine is, quite an inequal war in material, arms and population terms. Since 1978 the war of liberation is being carried out with constant intensity. Despite heavy losses and all other odds the Mujahideen, believing in God and the liberation of their homeland, will not submit or surrender to the invaders.

The current Afghan war of liberation differs from the liberation movements of other nations in two aspects:

Firstly, the majority of liberation movements in Asia and Africa were struggling against Western colonialism and the Soviet Union has always pretended to be "The natural ally" of the liberation movements. Many of these liberation movements have rightly or wrongly been stamped by Westerners as radical, nationalist, communist or pro- Soviet bloc. Unlike some of these liberation movements, the current Afghan resistance opposes the same pretending "natural ally" the Soviet expansionists.

Secondly, other resistance movements were started mainly by one party, if there were more than one party the dominant one had the major role. In Afghanistan not all the resistance was related to the parties; rather, tribal and provincial groupings played a major role in mobilising the people for the jehad. The majority of the Afghans did not have much knowledge about the future plans of the Soviet-backed regime responsible for the coup d'etat of April 1978. However, a spontaneous resistance against the communist- oriented Khalq/Parcham factions started in different places. Local groupings led the resistance in their respective areas and some political parties and organizations were formed later, once the resistance had already been established. 
Social anthropologists have divided human communities into simple and complex categories. In light of this division some sociologists and anthropologists have designated the Afghan society as simple, but the current Afghan resistance proved this society is in some aspects as complex as some modern, technologically advanced communities.

The Khalq/Parcham factions were very naive in their understanding of the complex social structure of their own society. The main cause of their absolute failure in the attempt to apply an alien ideology in Afghanistan was that they based their understanding on very misleading analyses by Soviet ideologues concerning Afghan social structure. Neither the Soviet ideologues nor their imitators in the Khalq/Parcham factions realized that the socialist experiment was not in conformity with the Afghan social character and temperament.

In order to gain a better understanding of the Afghan resistance, we shall attempt to explain somewhat complex dimensions of the Afghan society.

\section{HISTORICAL BACKGROUND:}

Afghan society in general and the Pashtun tribes in particular are decentralised communities. Since Ahmad Shah Durrani (1747 - 73,), the Afghan monarchs were content to enlist soldiers through tribal Sardars (tribal chiefs with military titles), chieftains and elders from the Pashtun tribes in time of emergency. Whenever the time of offensive or defensive operations was over, the soldiers were allowed to go back to their homes and continue their traditional farming activities. The spoils of war were also distributed among the recruits.

Non- Pashtun or other ethnic groups, living in or close to the capital under the government's protection, were taxed by the ruler and some military recruits were also drafted from these communities. There had been conflict of interest between the king and the tribes. To solve this problem Ahmad Shah tried to strengthen the central government. He gradually increased the army from 16000 to 120000 men. Despite all this strength Ahmad Shah did not interfere in the internal affairs of the Pashtun tribes,but left them to their traditional way of life. His political regime was a sort of tribal confederation and according to Rejsner he was "primus interpares," first among equals. In 1809 during the reign of Shah Shujah, Elphistone arrived at Peshawar and wrote." The present King, like his grand father Ahmad Shah, does not take major action, without the consultation of Durani elders"1 Furthermore, it was not only in the selection of Ahmad Shah, but also in the selection of his successors that the Pashtun tribes and other ethnic groups played an important role. Elphinstone adds: "An ordinary king would try 
to bring the tribes under his control with power (or try to subjugate the tribes by using power) while a Pashtun king (Ahmad Shah) has discovered this secret in advance, that it requires less power to bring a foreign country under control, than he would need for the subjugation of his own people"2

The situation of frequent change of the Afghan rulers destabilised relations between the centre and provinces, until Amir Abdur Rahman (1880-1901) gained political power in Afghanistan. Although the "Iron Amir" established a strong centralised government in the country, there was hardly any tribe or village that had not shown active opposition to his centralisation policy. After his death, the internal opposition against his successor, Amir Habibullah (1901 - 1919), was relatively calm. Neverthless, the Pashtun tribes maintained their centrifugal characteristics due to their distance from the central government and remained outside the full control of the centre, enjoying relatively autonomous status. All historical factors are the witness of political developments in Afghanistan that whenever the central government has tried to curb the traditional freedom of the Pashtun tribes, they have reacted definitely against the encroachment. For example, the revolt of the Pashtun tribes in Khost (Paktia province) in 1924 against the reforms introduced by King Amanullah (1919-29) continued for several months. The uprising of 1929 against Amanullah resulted in the downfall of his monarchy. The uprising of the Safi tribe in Kunar Province, in 1947, is another lucid example of the freedom of Pashtun tribes.

\section{SOCIAL STRUCTURE:}

The autonomy of the Pashtun tribes to a large extent depends on their segmentary structure and "Pashtunwali", the tribal code of conduct. This means that the Pashtun tribes neither accepted the sovereign authority of the central government nor created centralised institutions. The main reason for this is that they already had a traditional code and all their internal and external relations were organised on the basis of norms and values of this code.

Almost all social affairs are conductd through the elaborate Jirga (Tribal council) system which Elphenstone calls, "the democratic politics of the Pashtun tribes". Sigrist $^{3}$ Glatzer $^{4}$, and Steul ${ }^{5}$ agree in calling the Pashtun community segmentary, egalitarian and acephalous in character. Sigrist, applying Evans - Prichard's model developed for the Nuer tribe in Africa, refers to the Pashtun community as "ordered anarchy. The important characteristic of ordered anarchy is no sovereignty exists, the people of such communities are free and have no established organizations. In many aspects such a community resembles the old acephalous community, and due to its 
geographical isolation, sovereignty can not be developed. The colonialist powers often give themselves the right to bring these communities under their cultural and political domination, according to the Theory of Racism which assumes that the aboriginies do not need soverignty, because they neither have knowledge of sovereign organisation nor can they establish it. These two generalised concepts have been proved false. ${ }^{7}$ Sigrist assumes that in segmentary societies the consciousness of equality, democratic values and norms are the main obstacles on the way to the establishment of authority and sovereignty. He says that in segmentary societies there are non-political regions which are homegeneous social areas, and that is why political centres can not be established. There is very little division of labour and political expertise, and social stratificaion does not exist. Another important factor for the lack of a sovereignty centre is that the people either do not try to have it or fear its direct contradiction with their norms of equality. 8

Sigrist does not claim that all the segmentary societies are egalitarian in every way. For example, in some African communities inequality in sex, technical expertise, polygamy and ownership of livestock are indicators of of social and economic differences. Alongside these indicators he also lists those tendencies and norms which guarantee social equality. For example, the necessity of division of material things among the African community of Nuer or in the Lygbara tribe is such that the youngmen of the tribes, working in the cities, send their earnings to the tribal seniors, not to the family elders. In some cases there are no primogeniture rules, rather, the property of the father is divided among all his brothers not among his sons.

In egalitarian communities people show reaction against the rich. Glatzer has given a good example from the Durrani nomads in Afghanistan, as follows:

A man by the name of A.A. had a large herd of sheep and was hospitable to the guests in his guest house. Finally he became a candidate for the position of "Khan" (cheiftain). Some times he used to mention that he felt himself like a Khan. Gradually he was caught in social isolation, separating his sheep from the common herd and excluding his relatives from the communal pastures.

Although the pasture was not that important, actually the people did not want him to be the Khan. His social isolation became known to him and to others when men did not show up at his house during Eid (days of Muslims festivity).

It is a general custom that on these days all men and women visit one another's homes for congratulations and visitors are served with good food. On these particular days only women visited A.A.'s house. 
Some time earlier A.A. had quarrelled with his father-in-law about a wedding case. He asked his father-in-law to leave the pasture. The father-in-law ordered the women to dismantle the tents and pack them up. Before the women started to bring down the tents, all of the people of the area, including two of A.A.'s brothers, came to the father-in-law and asked him to stay. After this incident two of the men of the area told Glatzer that the people were not interested whether the father-in-law of A.A.'s stayed or left the pasture, but the most important thing was that the people were determined to prevent A.A. from becoming a "big gun" and playing the role of a Khan."

There are many examples of such intertribal rivalries. The reason that the Pashtuns of every village and town have attached their lineages and clans to different politcal parties lies in their strong sense of eglitarianism. It reveals a sort of dualism of uniformity-diversity in their tribal structure, which is the main source of rivalries among the Pashtuns from the tribal level own to the family unit.

It seems that whole Pashtun tribes, such as Tarkani, Yusufzai, Marwat Bangash, Shinwari of Shegal in Kunar province, Barits in the Shorawak district of Kandahar and others, may have had the Vesh system (periodical distribution of land). The pattern of the Vesh system may have differed from one tribe to another, but as a general rule the common land was distributed among those who were members of the tribal commonwealth. This distribution remained in effect for one year (in the Barits tribe this practice still continues) up to twenty years (as in the Tarkani tribes). There were three types of land distribution, Khula Vesh (literally, distribution according to mouth), Malatar Vesh and Khula Vesh. In Kurani Vesh the land or the production of the common land was distributed according to the number of male and female members of a given family. In this sytem every member of a family had the right to an undeniable share in land and production. In the Malatar Vesh the land was given to those adult male members of a family who were capable enough to defend their common land against other tribes. In Kurani Vesh the distribution assumed consanguineous or geneological patterns. According to this practice the land was distributed among the male members of partrilineal descent.

According to our findings the Khula Vesh seems to be the oldest of all. From this system the Malatar Vesh has evolved in due course and on its part gave way to the Kurani Vesh. Although it is difficult to prove with documents whether the Vesh, was routine in all Pashtun tribes or not, there seems to be great equality in all the tribes. For example in Paktia we could not trace out the Vesh, but nonetheless the tribes who possess common forest, distribute it in parts among those grown up males of families who 
defend it and accept indemnity. This type of distribution resembles the Malatar Vesh ${ }^{8}$. In this respect Rejsner seems close to the fact when he states "in old days the periodical distribution of land existed among all Pashtun tribes"9. In short for the egalitarian consciousness of the Pashtun tribes, we can refer to their economic infrastructure. Meanwhile, we support Sigrist in his view that in segmentary communities the norms of egalitarian consciousness revive social equality. ${ }^{10}$

Except among the Barits of Shoorawak, the Vesh system has disappeared e.g., among the Mamund and Salerzai (Tarkani sub-tribes), 45 and 65 years ago respectively. In Banu and some other settled areas the distribution vanished when the British government introduced the new catester system and land was taxed. Distribution has not been practiced for quite some time now, while socially speaking the sense of egalitarianism is still evident among the Pashtun tribes. Pashtuns attempt to keep their autonomy and rights intact is a reoccuring event in Afghan history. The safeguarding of this right is those natural and social conditions which have been clearly expressed in th code of Pashtunwali. We earlier called the Pashtun community an ordered anarchy, because the norms and values in the code include collective, comprehensive relations of Pashtun life. This is why Steul recognises Pashtunwali as a legal code and describes it in 6 points. For our purpose we only mention 3 of the points:

1. The Pashtun is free.

2. Pashtun tribes are free.

3. Ownership of land guarantees the social existence of an individual, tribes and their freedom. Nobody has the right or is allowed to take away the right of their freedom or impose limitations on it. ${ }^{11}$

We cannot explain all the norms and values of the code of Pashtunwali in this article. Rather we dwell here only on those norms of the code which are considered important for the social relations of the Pashtuns, relative to the current resistance.

Most Pashtun problems arise from Zar (wealth), Zan (woman) and Zamin (land), and these three things are very sacred to the Pashtuns, called collectively Namus (honour or chastity). Defence of Namus is the most important part of the code and a Pashtun must defend his honour by all means. For him injuries and even death in the defense of Namus are inevitable. Wealth, Women and Land were the categories which the communists in Afghanistan attacked first. It is an undeniable fact that the communists nationalise wealth and land but the common people in Afghanistan believe that the 
communist regime also gradually turns a woman into communal property. The communist coup d'etat not only challenged the Pashtun Namus, but also interfered with private possessions, which according to the religion of holy Islam are immune from unlawful interference. In this case the legal and economic dimensions of Islam and the norms and values of the code of Pashtunwali took a parallel stance and supported the anti-communist resistance movement throughout the country.

The Russians consider the Pashtuns a backward semi nomadic people scattered in due course of history from the Suliman Mountains in both directions east and west. Gradually the Tajiks 12 brought the Pashtuns under their cultural influence and lived with them as neighbours. The Tajiks were urban and the Pashtuns more rural, that the nomads carried out semisedentary pastoral lives within the framework of the code of Pashtunwali. To the Soviet colonial power this code was the main obstacle for the expansion to rural areas of the Pashtun tribes and so the Soviets in the latter part of their direct invasion of Afghanistan relied on the Parcham faction, whose majority came from the urban areas. Parchamis relations with the land and country have been weakened considerably, if not lost altogether. For this reason, they were the most likely group to accept the slogan, "workers have no country", easily. This is the main reason that the Parchamis became cheap traitors to their people and motherland. The reason why the Khalqis and Parchamis were used by the Soviets one after another for the implementation of their political interests will be analysed in another article.

Here it has to be mentioned that Afghan nomads participation in the current Jehad was below expectations in comparison with their arms and manpower strength. One of the reasons for their lagging behind the other freedom fighters is that the majority of the nomads do not own land and their economy is based on extensive animal husbandry. Their grazing areas cover both Pakistan and Afghanistan. Another reason of their lack of big share in the Jehad is that the very economic structure of the nomads is not made for the war. ${ }^{13}$ The nomads who migrated in the early part of the Jehad and did not return in summer to the pastures in Afghanistan, lost a major part of their flocks. Similarly the nomads living in Afghanistan also lost their animals due to the indiscriminate bombardment of the sedentary population. Furthermore, the economic blockade of the urban areas by the rural population angered the Russian and the Karmal soldiers, who wherever saw the animals, grabbed them by force for their own consumption without any compensation. Only those nomads got compensation who had direct or indirect relations with the Karmal regime. 


\section{TRIBES' RELATION WITH POLITCAL PARTIES}

At the end of the seventh term of the liberal parliament in Afghanistan, Mohammad Daud took over political power as prime minister, in 1953. He intended to put Afghanistan in the path of economic development in a very short time. For this he needed tranquility in the country and chose to rule over Afghans with an iron hand. At that time westerners were of the opinion that the underdeveloped countries needed benevolent dictators to increase the tempo of progress in their backward societies. Though the USA and European countries took active part in development programmes in the state sector, the aid-giving governments stayed away from investing in the private sector. There was an assumption in the government circles of the west that sooner or later Afghanistan would become a satellite in the Soviet orbit. Initially Mohammad Daud asked the USA and other Western countires to help Afghanistan in the modernisation of her military, economic and technological sectors, but all of them attached conditions to their aid. They indicated to him that the aid would be provided under the condition that he join either the SEATO or CENTO pacts.

The wily Soviets were observing the situation very carefully. When the USA and European powers rejected his request for aid, the Soviets came forward and Mohammad Daud, the ambitious reformist, could not pass up the Russian offers of aid, especially in the military fields. He signed arms agreements, yourg Afghan military cadets were sent to the Soviet Union for higher education and Soviet advisers were invited to help the Afghan officers in the modernisation process. Afghan and Soviet relations were strengthened and together with arms, Soviet style communism also entered Afghanistan. The official circle in Kabul accepted every thing in the name of development and even the communist elements were considered a progressive segment of Afghan society.

In 1963 Mohammad Daud was replaced by Dr. Mohammad Yusuf and the era of democracy (1963-73) started. For the first time under the newly promulgated constitution a fair election on non-party basis was held for the parliament. Though the constitution had an article allowing for party formation, but did not allow party activities until a bill of approval was passed by the parliament and signed by the king. Nevertheless, the Khalq party, formed in 1965, started to publish a weekly "Khalq". Activities of invitation and attraction to the party commenced in educational institutions. $^{14}$

For 25 years (1953-78) the Russian worked hard to form communist cells in the Afghan Army and establish the civilian communist party, PDPA 
(People Democratic Party of Afghanistan). They schemed that if the army snatched the political power the party would take charge of affairs. Fourteen years after the formation of the party, the same military personnel, trained and brainwashed by the Soviets, staged a bloody coup d'etat and the party took political power. This was a conscious move on the Russian part. According to the Soviet ideologues the army in a Third World country is most modern, disciplined and well acquainted with the operation of highly sophisticated war technology and can easily be turned in to a revolutionary force against a regime which the Soviets do not like for some reasons. The Soviets have different experiences with coups in Third World countires. For instance they turned the Egyptian coup d'etat of Jamal Abdul Nasir to the socialist fold and used it against the West. In any case, there are differences between the Egyptian and Afghan Armies. The main difference is that the Egyptian coup d'etat was staged by nationalist officers, while coup in Afghanistan was led by the communist officers who lacked national character from the beginning and this Soviet - orchestrated coup d'etat worked only for the Russian expansion. The Russian took advantage of the Afghan Army as an operational force, and contrary to the popular notion that the army was attached to the party, rather in our opinion, the party was attached to officers brainwashed in the Soviet Union since 1955. These Afghan officers were ready to act whenever they were ordered by the Soviet adivsers for operations.

The main reason for the uprising of the people against the Khalq/Parcham regime was that this party had alienated itself from the people. Since its formation the party members did not hide their traitorous anti-national, anti-Islamic, and subservient character, mostly serving for international communism rather than for the national interests of Afghanistan. This bunch of underlings were marginal elements in Afghan society and were not accepted by the people, therefore, it was very hard for the people to accept these Russian proxies, their reforms and their alien ideology.

The spontaneous uprising first started in Kunar, Paktia and then gradually spread to other provinces and at last to all parts of the country. The people of every tribe, village, town and city began tough resistance under local commanders to liberate their own areas. In the beginning the influence of Jehad organizations outside the country was not as much as it is now. Afterwards many political organizations came into existance and now the Mujahideen inside and the refugees outside are related to every one of these organizations in one way or the other. Despite this fact the tribal and ethnic organizations are still strong social institutions for Jehad.. As mentioned before by sociak structure Afghanistan is a tribal and semi-tribal 
society and it requires a long time to bring a change in its infrastructure. Until now different tribes, ethnic groups and minorities have lived together within the political boundaries of Afghanistan, which in its historical perspective is a nation state but not a national state in the modern sense. In Third World, national consciousness and national states are unusally created during their struggle against foreign domination and after independence the national state comes in to existence. Similarly different nationalities in Afghanistan are struggling against a common enemy, and during this process the Afghan nationalities are on the way to fuse together and in future will make a national state based on their religious and national traditions.

In this prevailing circumstance the hodge-podge people of Afghanistan have no alternative except to get together around a country-wide liberation resistance movement and continue their Jehad to the end. From the start till now the Afghans are hearing loud voices for unity. Sometimes their hope and expectation have risen very high, but days, months and years have passed without getting close to this paramount goal.

The leadership of political parties and organizations is composed of educated or less educated ones. The reason we emphasise the importance of tribal organizations is that the illiteracy rate in Afghanistan is very high, approximately 80 to 90 percent. The educated segment, created in the last forty years, was reduced to a very small number by the communist regime.

Afghanistan lost a great majority of the non-communist elite. Many of them were killed, some were forced to leave their homes and the remaining ones inside are living in very suffocating conditions under the imposed communist regime. Thus, in a tribal and rural community like Afghanistan the political parties can hardly claim more than one thousand educated members.

One might ask why the Jehad started in Kunar and Paktia provinces first. The main reason was that in these areas the tribal institutions played the role of party organizations, which have many efficient characteristics. Here we refer to a few of them in brief:

Fristly, tribal organisation includes all the members of a given tribe and no one is left outside of the tribal fold. Thus, one can count on the whole tribe and a large number of tribesmen can easily be mobilised for war or other emergencies.

Secondly, the Jirga system of the Pashtun tribes is based on a democratic procedure. Everyone of the participants has the right to express 


\section{Pashtun Tribes and the Afghan Resistance}

himself freely and the concerned problems are often solved by general consensus.

Thirdly, there is a positive rivalry among the elders in the tribal organization. This is not like party rivalries, which in many provinces (except Paktia and Paktika) have sometimes infighting and killing among the Mujahideen. Rivalries among the tribal elders are checked by the tribal code of conduct and no one is allowed to take revenge in a tribal emergency.

We wish to present Paktia as an example of the tribal organization. In 1979, the tribe of Zadran launched a successful attack on the government forces on the highway from Urgoon to Khost and from Khost to Gardez. In this attack the military convoy and the civilian and military centres of the government in the Zadran area were completely destroyed and since that time the whole area has remained liberated. Several times the communist regime attempted to reopen the blocked road to recapture the liberated area but tribal organization repulsed each attempt decisively. Until now the communication line of the Karmal regime with Khost is by air, not by road. After the Zadran operation all the surrounding tribes of Tani, Sabari and others declared holy war against the communist regime. It will be difficult to explain the organizations of all the tribes which have played an active role in the resistance. Since our information regarding the tribe of Tani is more reliable than for other tribes, we present it as axxample of a tribal structure and its functional characteristics.

Tani are mountainous people and their tribal territory is located in the southwest of Khost. The plain region occupied by the tribe gradually losses altitude towards the Khost valley. It is a dry land and dry farming is most common in the area. Before the Jehad most of the Tanis earned their livelihood by selling wood. Now many of the young men of the Tani tribe go to the United Arab Emirates and Iran for employment. At the end of the 19th century, the population of Tani sub-tribes was estimated at 3000 men, but now their population is 15000 men. Genealogically they are considered the descendents of Shetak and the tribe is divided into three large clans, Mari Khail, Aryouzi and Seenaki. These three clans are divided into many subclans, sub-clans into lineages which come down to the family unit.

Here we take only Mari Khail as an example to show Tani's geneological structure: 


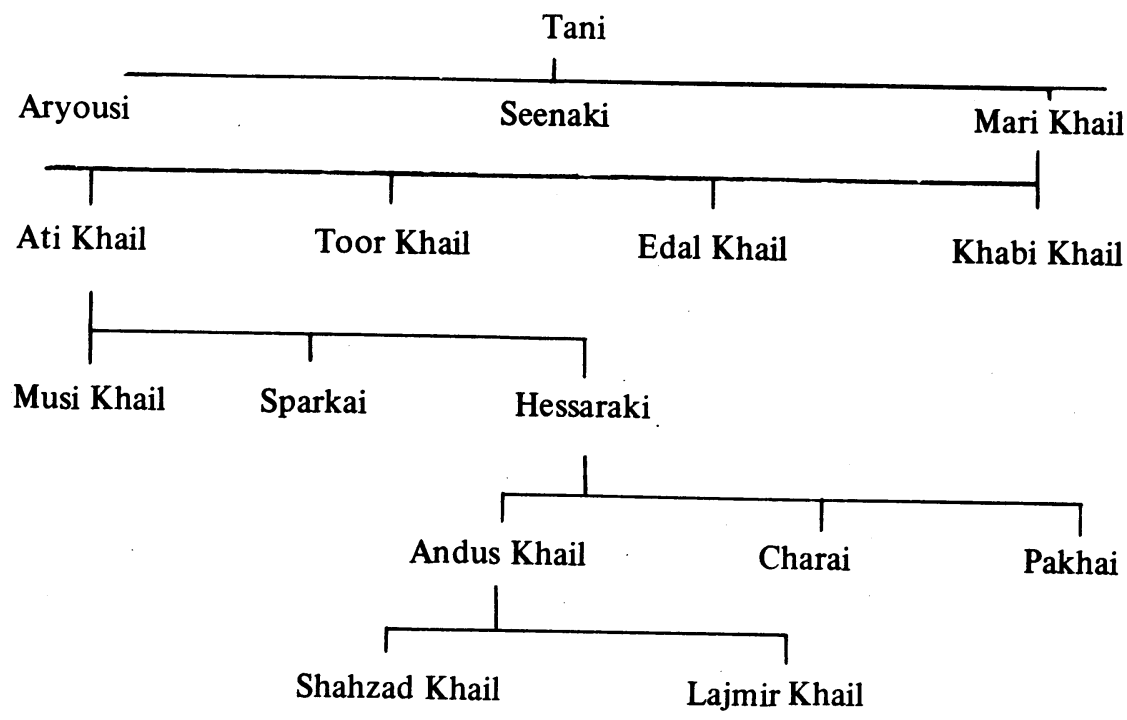

As in other tribes, there are intersegmentary rivalries among the Tani sub-tribes down to the family unit. For instance, if there is a conflict between the Mari Khail and Seenaki, then the members of Mari Khail clan stand against the Seenkai clan. Likewise if the Tani tribe is involved against another major tribe in the area, in such case the whole Tani tribe becomes one body to defend itself against the rival tribe. If there is a conflict between a Pashtun tribe and non-Pashtun elements in the area, in this conflict all the Pashtun tribes support the involved Pashtun tribe. If there is a foreign danger to the whole area, the Pashtun and non-Pashtun elements come together and resist the foreigners. A vivid example is the present stand of all Aighans against the Russians.

Each clan has its elders and they are chosen by the clan members for their family background or for their personal merits. The clansmen listen to their notables and the heads of the clans receive different responsibilities for their own people. The Jirga of elders is considered a decisive or determining organ of the tribal organization. To organize the social life; of the tribesmen the Jirga can adopt appropriate decisions in different circumstances, and also execute the existing tribal norms. For instance, they determine the punishment and fines for wrong-doers and decisions are put into practice without any delay.

To fulfill the decisions of the leaders, "Arbaki" or tribal militiamen are recruited. Their numbers may vary from forty to 300 persons depending 
on the magnitude of the problem and the circumstances. The act of recruitment is called "Tsalvekhty" or "Forty" because in most cases only forty persons are recruited. Only in the case of emergencies or other major tribal conflicts the number is raised beyond forty, upto three hundred. Four or five persons are elected as heads of the Arbaki. They serve as commanders. The members of Arbaki have to listen to their commanders and obey their orders at all times, and the leaders of the Arbaki in turn derive their guidelines and directive from the Jirga of tribal elders. Whenever the Jirga makes its decision and determines the fines or punishment of a person for a crime or offence, the decision is passed on to the Arbaki commanders for execution or collection of the fine or for carrying out other duties.

Although the code of "Pashtunwali" covers all aspects of the Pashtun tribal social values, in this article we cannot explain all the legal codes, norms and punishments, which serve as the apparatus of a central government. In order to give an idea about the functions of the institution, we will try to describe in brief by giving the example of the Tani tribe punishments related to the present Jehad.

Among the Pashtun tribe revenge is a common phenomenon. Nobody has the right to kill another without reasonable justification. If one does so, then the heirs of the murdered person have the right to take revenge, but the people of Tani have decided that as long as the Jehad continues no one is allowed to take revenge of age old feuds. In case someone takes revenge or kills another without justification, he is subject to a fine of four hundred thousand Afghanis in cash. He is forbidden to cultivate his land and his house is burned down. This is the punishment determined by the tribes. If someone has an animosity toward another, they can settle their dispute at the end of the Jehad. Those tribesmen who chose to cooperate with the Kabul regime are not allowed to enter their tribal territories. If they do so, they are fined four hundred thousand Afghanis and their houses are burnt. Of course, those who have not harmed the people are not supposed to receive any penalty.

Those tribal members who leave the tribal territory and are in the service of the Karmal regime in one way or the other, are also subject to the above punishment. If anyone is cought spying for the Kabul regime, he is punished severely. In some cases he is sentenced to death.

The tribe of Tani as well as other tribes in the area have cut down economic ties with the Khalq and Parcham governments. If someone brings food items or fire wood to the city of Khost or to the area which is under the control of government troops, he is subject to a fine. For example, a donkey load of fire wood is subject to a fine of 500 Afghanis a camel load of fire wood 
to 2000 Afghanis.

The people of Tani, until the Russian invasion of Afghanistan due to the flatness of the land, did not fight overtly against the government, but recruied seven hundred Mujahideen and stationed them in different places for Jehad. But after the Russian invasion the people could not remain silent anymore. All held a meeting in a place called "Akbari" and passed the above mentioned resolution for punishments which is known as the "Akbari resolution."

In the spring of 1984, the government organized regiment of Tani and distributed 700 rifles to them. Although this regiment did not wholeheartedly collaborated with the Karmal government, despite this the elders of the tribe collected all the weapons from thoese received them and redistributed them among all the tribesmen according to the existing tribal shares. Apparently, the majority of the recipients of these rifles were Mujahideen. But the matter was very important politically. By realottment of these guns among the tribesmen, the government's undesirable goals were defeated. This process was accomplished peacefully, without much difficulty, and without any incidnet. This matter might not have been solved if there were not a strong tribal organization. We have attempted to present comparative information concerning the functioning of a tribal society. To those whose study or knowledge is not adequate concerning the Afghan tribal community and the ongoing resistance, we may look naive and traditional and they might think that we are sympathetic to the code of conduct of the old tribal organizations. We are fully aware that the tribal organizations are traditional and very old in comparison with a modern political party and modern enemy who uses all modern technology in the battlefields. Nevertheless, in Afghan society compared to the communist party, recognized influencial personalities in Jehad play a major role and are considered very important.

We are certain that the Afghan resistance cannot succeed without a real, united front. Whenever we are able to establish a committed, united, political, military, economic and cultural front againt the common enemy, it is then that we should expect major victories in every field against the adversary. 


\section{NOTES}

1. Elphinstone .M.: The Kingdom of Caubol, Pashto translation, the Academy of Sciences of Afghanistan, 1981, volume 1.p. 190.

2. ibid p. 190.

3. Sigrist, chr.: Regulierte Anarchie, Syndikat 1979, Frankfurt/M. p. 28

4. Glatzer, Bernt: Die Nomaden Von Gharjistan, Wiesbahen 1977

5. Stuel, Willi, :Paschtunwali ein Ehrenkodex und seine Rechtliche Relevanz.

6. Sigrist, Chr: Regulierte Anarchic, p. 159

7. ibid, p. 159,160

8. Amin Rasul and Taniwal Hakim, unpublished Manograph on the Socioecomic structure of the Pashtuns.

9. Rejsner, I.M. and Barth mention this also for Swat in the first time of Vesh. Barth: political leadership among the Pathan in swat, 1959 and Rejsner: Razvieti Feodalizma....1954 Moscow. scow.

10. Sigrist, chr.: Regulierte Anarchie, p.202 203

11. Steul, Willi, ibid P. 244, 245

12. Great Soviet Eneyclopedia, Moscow 1954.

13. Glatzer, B. ibid, p. 200

14. See Dupree, Louis, Red Flag Over Afghanistan. 



\title{
RUSSO-AFGHAN RELATIONS
}

\author{
by
}

Mohammad Asef Ikram

The strategic Afghanistan, situated as a crossroad of Central Asia, Middleeast and Indo-Pak subcontinent, has always been the highway of conquest of the bloodthirsty invaders. From time to time in our history, whenever the intruders have intended to crush and conquer the Afghan people, our ancesstors have always fought for their liberty and independence. The Afghan history is a witness of this fact that all the invaders have often called our national liberation struggle as a rebellion by a wild and semi-civilised people. By giving such impressions the main object of all of them has been to furnish justification and legalisation to their brutal aggressions.

Alexander, the great, (330BC) ${ }^{1}$, Changiz Khan $(1221 \mathrm{AC})^{2}$, Halako, $1254^{3}$, and Taimur, the lane $1380^{4}$ crossed and recrossed the Afghan land and each one committed genocide and destruction of cities, villages and houses of the resistants on their way to the conquest of other lands. But the only difference of the former invaders and the Soviets is in the instruments for the killing of the inhabitants of Afghanistan. The former aggressors came along with their hordes ridding on the horses on a few beaten tracks in the mountaineous and plain areas and killed only those who were living on their ways to the conquest and resisted the aggressors. It was very hard for the former aggressors to climb up the mountaineous terrains or divert their routes to far flung areas. Contrary to all the invaders in past, the present Soviet aggressors have invaded Afghanistan by land and by air. Their tanks and airoplanes destory cities, towns villages and hermits in the plains and mountains all over the country and kill human beings, cattle and animals alike.

Since Sixteenth century the expansionist Russian empire builders had determined to extend their frontiers in all directions. In the north they have 
been blocked by north pole, seaboard in the east and by powerfull nations in the west. Throughout the centuries the Russians made thrust to south and east towards constontinople and Central Asia. Europe, of course, resisted against Russian expansion in constontinople but their advance in Central Asia halted due to the British rule in India.

- Russians had been advancing to Asia for centuries slowly and systematically without allowing themselves to be diverted from their main objective of colonisation.

- She was not satisfied with mere conquest of foreign lands, but she tried hard unremittingly to assimilate and Russianise the countries annexed, and achieved considerable positive result in this respect.

- Russia established herself firmly in Asia. She had no menace from any quarter, and had nothing to fear from the subjugated people, rather she always utilises them for military services and construction labour. 5

The Tzarist Russia always established permanent social and military institutions in the occupied lands for the conquest of the neighbouring nations for her next step of expansion. The Russians relied on those who supported them and not their own national cause. There was a hatred for the religious and social institutions of the occupied peoples and the chauvinist Russians regarded themselves as the only chosen and civilised race in the world.

The inclination to conquer the neighbouring countries and expand in all directions has been a peculiar legacy of the Mongolian period for Russia throughout the succeeding centuries up to now. This view leads, however, to the idea of universal empire, an idea, even if it may be unconsciously, has prevailed not only in the very political system of the Russian government but in the social structure of the Russian people too. To it must be ascribed the intuitive desire for conquest which has displayed itself both among the Cossacks and various other "tools" which executed the orders of the Tzars on the confines of the empire. Even central government was always supporting the successful enterprises of the subordinates, even if their enterprises were against the very instructions of the central authorities. This idea of universal empire has determined the political ideals of the Russians. In Asia the Russian masters took up themselves as heirs and successors to Changiz Khan and Taimur, the great conquerors and rulers who were the true 
believers in universal kingdom under their ways.

Whenever, the circumstances have allowed everyone of the great rulers of Central Asia, he has launched a campaign to conquer India. This is the main reason that the great rulers of this part of the world have extended their frontiers to the sub-continet. Peter, the great Russian ruler, also took keen interest to find water routes to China and India and in 1716 he gave orders for the expedition to explore the south. 6

During the first years of the 19th century, the Russians were engaged in taking over the Qarqhiz steppes, and were still a long way from their present frontiers with Afghanistan. In 1838 the Russian government persuaded the Persians to lay a siege to the strategically situated city of Herat. Russians aims at that time were merely commercial. 7

The strating of rivalry between Great Britain and Russia in 1815 influenced this part of the world. ${ }^{8}$ Afghanistan became the arena of the great game. During the 19th century and in the beginning of the 20th century, Britain was the pioneer in competition with Russia in this region. British forward policy in the sub-continent resulted to impose three wars on the people of Afghanistan. During 19th century Afghanistan kept on balancing her foreign policy toward Britain and Russia. Russians feared about the Central Asian states whose loyalty to Russia has always been in doubt. Russians feared that the Afghan rulers might draw off Central Asian confederation under their rule with the British assistance. Both Britain and Russia wanted to ensure their security from the one another.

Before the World War II, the Afghan Soviet relations were not cordial. The Soviets had certain political interests for their long-term strategy of reaching to the warm water of Indian Ocean and consequently Afghanistan became the victim of the competition of the two big world empires. 9

Amir Abdul Rahman (1880-1901), who had lived in the Russian dominated Central Asia, was fully aware of the Russian strategy in East. He did not trust the Russian friendship and knew this fact that a close contact with the neighbouring Russian colonist power was not in the interest of Afghanistan. As the Russian expansionist forces occupied.Tashkent, it became a direct threat to the very security of Afghanistan. Amir was compelled to reinforce Wakhan and Sheghnan in 1883 and Panjdeh in 1884 against the Russians. In 1884, the Russians occupied Marwa and in the next year, while the Amir was in India, the Russians invaded Panjdeh and annexed the Afghan territory to the Russian empire by sheer force. Amir had to sign the Durand Line treaty with the British India in 1893 to guarantee the security of the remaining territory and borders of the country. 10

In 1920s, during the debate on the "National and Colonail Questions"11 
in the second congress of commintern, Lenin recognized the importance of supporting the nationalist movements in the Asian countries that the communists should forge a temporary alliance with national bourgeois for two purposes: Firstly, such alliance would weaken the imperialistic structure in the colonies and secondly this alliance would help the communists to develop their own communist parties in those countries. Lenin advocated "two stage revolution" thesis. In the first stage the communists should support the national bourgeois in their national liberation movements but must not merge their indentity with them. In the second stage the communists must use all means to take over political power and crush at once the class enemies and opponents to the communist system ruthlessly. And the communists should support only that bourgeois party or movement which does not oppose the efforts of the communists who organize the proletariats, peasantry and masses of the exploited class. ${ }^{11}$

After the independence of Afghanistan in 1919, King Amanullah established friendly relations with Russia in the hope that the new Soviet regime might help those peoples who had lived under the Western colonial rulers for years. On the other hand the Soviet regime also found it in its interest to take efficient steps towards their long term aims in the south. They extended their hand of friendship to Afghanistan and the result was a peace and non-aggression treaty between the two countries in $1921 .{ }^{12}$ After this treaty Amanullah gradually stepped back from the support of Central Asian Muslim liberation movement against the Russian domination. After the independence the Soviets accelerated their activities to recruit agents to support their long term objectives in Afghanistan as well as in the region. These hectic activities reached to the point when Habibullah Kalakani alias 'Bacha-a-Saqaw' took power in Kabul in 1929, some Afghans demanded Russians support to reinstall Amanullah and rescue Afghanistan from British dominance. After the negotiations in the border area of Afghanistan, Russians agreed to help but proposed the following conditions for the reinstallation of the deposed king. ${ }^{13}$

1. Afghanistan should sign economic contracts with Russians in large scale.

2. Russians should be allowed to excavate and survey the natural resources, oil, minerals etc. in Afghanistan.

3. Contracts should be signed in the fields of military institutions and cadets' training. 
4. In future, facilities to be provided for the Russian passage to the Indian ocean through Afghan territory. 14

These conditions were rejected by Afghans and prefered to struggle against Bacha-e-Saqaw independently. In 1929, the Russian troops crossed north-western region of Afghanistan to chase Ibrahim Baig, the leader of the national liberation movement of Central Asia. In 1930 there were some rumours that Britain intended to form a buffer state between Afghanistan and Soviet Union under the leadership of Ibrahim Baig. ${ }^{15}$ King Nader Shah sent some troops to Herat to.expel Ibrahim Baig from Afghanistan. Ibrahim Baig had to retreat to Russian side where he was arrested and executed. After this incident a treaty of neutrality and non-aggression was signed between Afghanistan and the Soviet Union in Kabul on 24, June 1931.16 In the 3rd article of this treaty, it is written, that any third party may not be allowed to export arms through their territories against the other. This article was written because the Russians feared from a possible British interference in Central Asian affairs. Another treaty was signed on 17 Sept. 1932, according to which the frontier commissions of Russia were allowed to keep an eye on the activities of the foreigners in northern Afghanistan. 17

Mohammad Zahir Shah, the former king, apparently attempted to keep a balance of neutrality of Afghanistan between Britain and Russia. But some undesirable conditions developed gradually which forced the Afghan government to tilt towards Russians and established trade, cultural, education and military relations with USSR. The then ambitious prime minister Mohammad Daud (1953-63) wanted to bring rapid modernisation to Afghanistan and for this purpose he asked first the USA, Britain and France to help him in the modernisation process. His request was rejected. Thus, Afghanis$\tan$ was pushed completely into the Russian sphere of influence.

The disgruntled and ambitious prime minister started to bring Afghanistan closer to the expansionist northern neighbour. He preferred to sign contracts with Russia in all develpmental fields. On 9 December $1953^{18}$, an Afghan education and cultural delegation under Dr. M. Aannas visited Moscow and signed education and cultural treaty with the Soviet Union which opened the way for the Afghan students to receive training in Russia in various fields. Unfortunately two ways traffic started. Afgah government was sending young officers and students to Russia and was bringing Russian advisors, experts, technicians and military trainers. This treaty is regarded the major cause of providing facilities for the growth of communism and atheism among some of the brain-washed young officers and students.

On January 27, 1954, the contract of building two silos in Kabul and 
Puli-Khumri was signed with Russia. ${ }^{19}$ On 15 December, 1955, Bulganin and Khurschev visited Kabul ${ }^{20}$. This was the first time that Russian leaders stepped on Afghan soil and their visit to Afghanistan was considered by many enlightened Afghans as an ominous incident in the history of Afghanistan. The Soviet leaders promised a long term 1 million dollars loan to Afghanistan.

A military delegation went to Moscow on April 24, 1956 21 , and signed the contract of buying various military equipments. Supplies of the equipments started soon after the imprisonment of Abdul Malik, Abdur Rahimzai on July 10,1957 . It was also a Russian conspiracy. 22 The real cause of his arrest was that he was advising Daud to keep a balance in relations with eastwest. One week after his imprisonment, Mohammad Naim, the brother of Daud, visited Moscow and a contract was signed in August 1957. According to this treaty only the Russians had the right of explorations in the northern provinces of the country and not the other foreign agencies. Actually this wasted all the works of U.N. experts in northern Afghanistan. After this treaty many K.G.B. personnel came to Afghanistan under the guise of engineers, experts, geologists, etc. Brezhnev the then member of Politburo, visited Kabul and laid the foundation stone of polytechnic institute in October, 1957 and large number of professors, lecturers, technicians etc. were sent to this institute which in reality was turned into a haven for the clandistine KGB activities.

On May 29, $1959^{23}$, the contract to asphalt Kandahar-Heart highway brought hundreds of more Russians in Afghanistan. On January 19, 1960, the contracts of irrigation project of Nangarhar was signed between the ministry of Public Works and Techno-Export Co. of the Soviet Union 24 . On March 14, 1960 a contract was signed to build Kabul Nandary with the expenditure of half million Russian roubles. 25

Treaties and contracts were signed between Afghanistan and Russia in various fields during the decade of Daud Khan's prime ministership. In this period the whole economic system of Afghanistan was tied to Russia which gave her substantial opportunity to study the Afghan society, establish contacts with the dissident elements and form clandistine communist circle in Afghan Army and civil institutions.

During the era of democracy 1964-73, many contracts were signed with the Soviet Union and this period also gave a golden chance to the Russian ideologists and politicians to act openly and work freely for the implementation of their sinister designs in Afghanistan. The formation of Khalq communist party on 1 st January $1965^{27}$, and its de facto recognition by the government actually legalised the dissimination and defusion of the 
communist ideology in the country. The split of the Parcham faction from the Khalq in 1968, caused a hectic competition between these two factions for the recruitment of communists. Parcham concentrated on the urban areas and Khalq on the rural sector. Some of the immature students coming from the poor and middle class families were converted into communists by the communist teachers in education institutions. The first target of these communist instructors was to alienate and brainwash the young stuff from their Islamic faith and national heritage by creating antagonistic feelings in them against their national leadership. The communist teachers always stressed on this redundant formula that the poor and deprived people had no alternative except accepting a communist regime under the centralised leadership of the Soviet Union for their rescue from poverty and deprivation.

The Soviet focused on the Afghan Army to stage a coup whenever they wanted to use this operational force trained and brainwashed by the Soviets. Both the Khalq/Parcham factions were assigned the task to do, as follows:

1. Both factions distributed communist literature in Afghanistan supplied by the KGB agents in Kabul or through Tudah Party of Iran.

2. Both factions praised everything done by the Soviets and condemned everything by non-communists or even by the communists who did not follow the Russian-line.

3. Both of them (Khaliqis in rural and Parchamis in urban areas) spied on other political parties, groups and individuals who were against the communist ideology or the Soviet domination. Both of them collected information about who was who and submitted their lists of information to the embassy of the Soviet Union in Kabul through the central committees of both factions. 27

It is very unfortunate to say that the then government did not take any effective and preventive measures to stop growing epidemic of communism in the country. Rather the rulling elite, deceived by multifaced Soviets, just enjoyed their privileges as rullers but never cared about the future of Afghanistan. Even the most knowledgable persons in the country, who did not follow the policy of the ruling elite, had been deprived to say anything about the dangers their country was going to face. Because the very stick yard of patriotism and treason was in their hands and the ruling elite were the only self-appointed judges to give their final verdict about everyone who was the patriot and who was the traitor. After the coup on 17 July, 1973, 
Mohammad Daud paved the way for a dangerous situation in the country:

1. He gave full freedom to the Parcham faction to dissiminate freely the Soviet style communism in Afghanistan. Many Parchamis were appointed as cabinet ministers and 160 as district officers throughout the country. 28 Right from the top cabinet down to the district and sub-district levels the rulling Parchamis preached communist ideology under Daud's protection umbrella. At this stage the Parchamis attracted some young girls and boys and opportunists to the communist fold and even made money by receiving bribes to be spent for their political activities. Faiz Mohammad, the then interior minister, was the real guardian of the Parcham faction. He appointed the activist Parchamis in important and sensitive posts.

2. Education ministry became a stronghold for the Khalq faction. Mohammad Wali Mandozai, director general of the employment department, brought the Khalqi elements to the important posts in the ministry and appointed the activist Khalqis in education institutions throughout the country. By their official influence the Khalqi activists recruited some teachers and young immature students for the Khalq faction.

3. There were a lot of Russian advisors in defence ministry who worked in all military institutions. Majority of these advisors were instructors in military institutions in USSR and had full acquaintance with the young Afghan officers while they were being trained in the Soviet Union. The advisors had a free hand to select the young Afghan officers for higher education in the Soviet Union and other socialist countries. And on their recommendations the Afghan officers, trained in the Soviet Union, were promoted to the most important commanding and operational posts in the ministry.

The Soviets had concentrated on the Afghan Army to indocrinate the young Afghan officers in the Soviet-style communism for implementing their short cut new thesis of bringing communist regime in the developing countries by military coup d'etat.

4. Between 1955-70, Moscow gave Kabul more financial aid than any other country outside the communist bloc. ${ }^{29}$ Upto 1979 , there were 117 projects in Afghanistan in economic, commercial, indus- 
trial, mines, agricultural, education, cultural, military, etc. which were assisted and supervised by the Soviets. The construction of the Salang Tunnel, Bagram and Sheendand air fields, installation of natural gas pipe-line in Jozjan, Nangarhar irrigation project, Kandahar-Herat highway, Naghlo power plant, Makroroyan housing project and all others were financed and.managed by Russians merely for their further expansion plans.

The Soviets had a well coordinated policy in Afghanistan to penetrate and monopolise everything in the country by reducing the influence of foreign rivals to promote their ideological and political interests.

In this era of big expectations the Afghan society was facing a great political vacuum which the leftist elements exploited in favour of the Soviet domination. As a result the consecutive coups of Mohammad Daud, July 17, 1973, accelerated the process of domination and the communist coup in April, 1978 completed it with the direct invasion of Afghanistan on December 27, 1979.

\section{NOTES AND REFERENCES}

1. Mir Ghulam Mohammad Ghubar, Afghanistan dar Masire Tariekh, "Afghanistan in the course of History", Payami-i-Mahajir Qum, Iran, 1359, p.43.

2. ibid. p. 208.

3. ibid. p. 226.

4. ibid. p. 258 .

5. Joseph Poposki, The Rival Powers in Central Asia, Ghosha-e-Adab, Quetta, 19'7, p. 65 .

6. ibid. p.32.

7. ibid. p. 84.

8. Tahir Amin, Afghanistan Crisis, Institute of Policy studies, Islamabad. 1982, p. 27.

9. Tahir Amin, (1982) p. 52.

10. Mir Ghulam Mohammad Ghubar (1359), p. 674.

11. Tahir Amin (1982) p. 50.

12. ibid. p. 52.

13. Dr. S.N. Haqshenas, "Dasayes wa Jenayat-e-Ross dar Afghanistan" (Conspiracies and Crimes of Russia in Afghanistan), Janiat Islami Cultural Committee, Tehran, 1363 p.68.

14. Ibid. p. 66

15. ibid, p.66.

16. ibid. p. 66 
17. ibid. p. 93.

18. ihid. p. 93.

19. ibid. p. 93.

20. ibid. p. 100.

21. ibid. p. 102.

22. ibid. p. 106.

23. ibid. p. 115.

24. ibid. p. 119.

25. ibid. p. 122

26. Tahir Amin (1982), p. 37

27. Prof. R. Amin, interview

28. Anthony Hyman, Afghanistan under Soviet Domination, the Macmillan Press Ltd. Hong Kong (1982) p. 66.

29. Tahir Amin 1982 p. 53. 


\title{
INTRODUCTION TO THE PASHTO TRANSLATION OF ANIMAL FARM
}

\author{
by
}

A. Rasul Amin

As the title of this work, Animal Farm reveals, it is not only a mirror reflecting the real features of brute Soviet communism, it is also one of the greatest political satires in English political literature which reveals the deeprooted contradiction of what the Soviet regime professes and how it diametrically acts in opposite ways.

George Orwell has written this masterpiece in symbolic form. Those who have not heard or read tales in which the animal characters speak and act like human beings or those who have no acquaintance with the historical background of the Russian communist party will not enjoy this book as it deserves. In this preface I would like to give in brief the biography of the author, the story of the Bolshevik betrayal, the author style of writing, and the symbolic characteristics of different animal characters of "Animal Farm". This should help the reader understand the objectives of the book and enjoy it.

\section{THE AUTHOR}

Eric Arthur Blair (1903-50) was born in Bengal, where his father worked for the civil service. The family moved to England and he was sent to school in 1911. Since his childhood this brilliant student was a talented poet and writer. He contributed regularly to various college magazines of Eton.

He left England in 1921, and joined the Indian Imperial Police in Burma. In 1928 he resigned and returned to England where he started worki reporter for different newspapers. In addition to many articles, he wrote novels, stories and biographies under the pen name of George Orwell.

The young Orwell was attracted to anarchism and afterwards became a 
socialist. At the end of 1936 he went to Spain to cover the fighting in the Civil War but stayed to join the Republicans fight against the Spanish communists. It was here he saw and experienced the immoral behaviour of the pro-Soviet communists who used all kinds of evil means in order to usurp political power. As a result of this practical experience with the communist, Orwell read Russian history, studies on Soviet style communism, reports and analyses of the contradiction between theory and practice of the Bolshevik Party, biographies of the actors in the party scenario, and records of important political events since October 1917.

\section{THE BOLSHEVIK BETRAYAL}

Contrary to the expectations of the colonised people, the Soviet regime opted to continue the Tzarist way of rule. Before October, 1917, communist party ideologues had committed themselves in all their written treatises and speeches to grant full independence to the Tzarist colonies and freedom to the Russian citizens after the overthrow of Tzarist regime. But as the newly established communist regime consolidated, all their former promises proved nothing more than betrayals, deceptions, and tyrannies both for colonised subjects and Russians alike. The new autocrats, ever known in history, declared all the former Asian and European colonies of TzaristEmpire as indivisible parts of the Soviet Empire.

Under the pretext of making a "new socialist society" and a "new socialist man", a hectic campaign was launched in all colonies by the communist regime to exterminate the entire historical, religious, cultural, social, political and economic heritage of the colonised peoples and pave the way for the Sovietisation and Russification in all aspects of their life. Under the slogans of discipline, obedience and loyalty to the party, the brutal espionage network of the communist regime chained all the colonised subjects to the Kremlin and deprived them of all human and civil rights. The communist autocrats declared a war of one party against all political parties, groups social segments and influencial personages in Russia, in the colonies, and among humanity at large. Thousands charged as reactionaries, nationalists, chauvinists, extremists, revisionist, bourgeois, feudal, aristocrats, bureaucrats, royalists, thieves, deceived ones, anti-ideology anti-party, anti-leadership, anti-state, foreign agents, collaborators and under hundreds of other false charges, were arrested and summarily executed.

The era of collectivisation of the farming and industrial infrastructure and the consolidation of party dictatorship (1929-39) resulted in widespread carnage among the peasantry, the so-called proletariats, party members, and 
intellectuals alike. It has been the most obnoxious characteristic of every self appointed reformist dictators whether individual or party leader, to make a mould for the reform of man and society. All dictators regard human beings as wax dummies. Stalin, one of the most bloodthirsty dictators of all time, made the mould in his image and put all the people with different social, political, economic, religious, cultural, ethnic and linguistic backgrounds into it. Naturally some were too big, (scholars, intellectuals, statesmen, advanced communities etc.) and some were too small (culturally backward peasantry, workers, tribal and traditional societies, etc). to be adjusted in the length and width of his frame. He had to stretch the small and squeese the big ones to fit them all alike in his mould. As a result the small ones turn into pieces and the big ones were bundled into his mould headless and footless. His frame was lying everywhere. It was in numerous torture cells, labour camps, prisons, offices of the spy network, centres of terrorists, death squads etc. It swallowed millions of peasants, workers, scholars, statesmen, intellectuals, politicians, civilian and military personnel even prominent members of the Bolshevik Party-in short, people from all walks of life.

As all socio-political segments, the remnants of the Tzarist era were completely crippled, Stalin paid keen attention to the children and youth of Soviet Russia and the colonies in the hope of producing" a new socialist man and the new mould of communist educational institutions-produced, "new socialist man" in his image to serve the communist regime. To the brainwashed "new socialist man" all the accepted human virtues and values were nothing more than the remains of ancient evils. He was armed with communist values. According to these values "the new socialist man" was, is and will be at the same time, the most loyal and obedient servant to the very person of the top dictators, the most active spy and propagandist, biggest liar and disinformationist, the coldest minded killer and terrorist, etc. In short, to him the only communist virtue has been to use all sorts of means for communist domination and consolidation.

Orwell found out that the deceiving ideology of the Soviet Union is in fact making a perverse human society which produces a new socialist man with a multiple personalities.

As a result of his deep perception, he presented to human society two masterpieces - Animal Farm, in 1944, and Ninetten Eighty Four, in 1949. His first masterpiece tells about communist ideology in action. In this book the author skillfully enumerates, how former promises are forgotten, how the rivalries among the communist leaders arise, how the party becomes an absolute despot, how a privileged new class emerges, how lip service is given 
to the dignity of work and the workers for their exploitation, how fiction is persented as fact and facts are presented as fictions and how people are made to believe in empty slogans.

\section{HIS WRITING STYLE}

As it appears from the biography of Orwell, he had accumulated considerable information about different peoples, and civilisations as well as stories about oriental despots, and knowledge about the Soviet dictatorship.

According to the tales, whenever a tyrant snatches away the right of the people to express themselves and complain against tyranny and oppression, some activists against the dictator do not sit as mere spectators. If they cannot openly. raise their voices, then they express themselves through anecdotes, tales and stories. Their main object is always to teach the people by making them conscious of prevailing cruelties. The tale-tellers frame their tales in a distant past or far away places and use the names of strange places, fairies, devils, birds, animals and supernatural beings.

Animal Farm is such a tale told by Orwell as a critique of the great tyranny of a communist regime. He had written this masterpiece in the style of old tale-tellers. The original name of Manor Farm is changed in to Animal Farm. thus, he uses the names of English farms very far away from the land of tyranny. Following the style of the old tales he introduces his story' with different names of the animals-pigs, dogs, horses, cows, sheep, hens, etc. In his story all the names of human beings and animals like Jones, Snowball, etc, are English. In his story the Great Master neither mentions nor refers to the name of the Soviet Union, the actual centre of dictatorship and oppression.

A brief description of the symbolic names and events follows:

1. Jones is a reference to Nicolas Alexander, the last emperor of Russia. In his plot the author portrays a weak Tzar who is completely unable to govern his vast empire.

\section{Old Major}

This is a reference to the real founder of communist ideology. Old Major dreams and the next day he talks of communes, exploitation of labourers by the upper class, class struggle, rebellion, classless society, equality, fraternity, justice, etc. After his death, his disciples, the pigs, become very active in translating Major's dream into action. 


\section{Events}

The writer portrays in the second chapter of the book a good analogy between the spontaneous rebillion of animals in Manor Farm and the uprising in Petersburg in February 1917. When Jones and his men neglect to feed trie animals on time, the hungry animals break the store's doors. Fighting starts. At last Jones, his wife and the men are driven from the Manor Farm, thus without any preparation the rebellion is brought to a successful end. Likewise in February 1917, the citizens of Petersburg (Leningrad) were commemorating Bloody Sunday of 1905, when suddently this commemoration turned into a spontaneous strike and afterwards took the form of a rebellion. The tired soldiers of World War I also joined the citizens and helped to fan the uprising. Alexander resigned and a provisional government was installed. During this period the Bolshevik Party conspired to take over political power in the name of the Soviets and eventually succeeded in its objectives.

\section{Snowball and Napoleon}

The main characters of the drama in this book are these two young pigs. With these two characters Orwell depicts the ongoing tough rivalry and bitter enmity inside the communist party between Trotsky (Snowball) and Stalin (Napoleon) for political power.

Trotsky (1879-1940) way born in a Jewish family of Petersburg and Stalin (1879-1953) was born in a poor Christian family in Georgia. They were opposite personalities, although both were communist from youth Trotsky was a prolific writer, ideologue, eloquent orator and a man internationally famed for having a good command over political and military affairs, on the other hand, Stalin was a good administrator, but stubborn, crazy for discipline, and man of only local reputation.

When the Bolshevik Party got political power, Trotsky was appointed defence minister of the Red Army and Stalin was appointed as Commissar for nationalities. The former went to work to organise the Red Army and the latter started to reorganize the Tzarsit administration on the basis of cultural units.

As the uprising against the communist regime started in 1918. Kazan came under the White Guard's control. Trotsky arrived in Kazan and 
commanded the Red Army in the front lines under a rain of bullets of the White Guard. A year later the fighting against the regime intensified and Trotsky defended Petersburg boldly.

In 1920, the communist party celebrated Trotsky's victories and he was awarded the Red Army Banner for his military services. From the beginning till 1925, Trotsky was regarded as second only to Lenin, as a leader of the revolution, organiser of the Red Army, and father of the victories against the White Guard. But contrary to his fame, the documents and memories of the civil war do not mention Stalin's name in any prominent way. In the beginning their rivalry was a personal one for political power. But afterwards both of them gave their personality clash a basis in ideological differences. Trotsky came out with his idea for permanent revolution particularly in Europe. If there was not a socialist revolution in Europe, the Russian revolution either would collapse or it would be diverted from its humane course. On the other hand, Stalin wanted to consolidate socialism in one country and then export the revolution to other countries. Their personality clash made the communist party a house divided. Trotsky called Stalin a stupid, arrogant, violent and stubborn Georgain, similarly Stalin accused Trotsky of being an adventurer, a terrorist, an old Menshevik, a bourgeois-minded reactionary who wnated to destroy the acheivements of socialist revolution.

After Lenin's death (1924), the father of conspiracies befriended and sought the cooperation of Politburo members Zinoviev and

Akamenav to prevent Trotsky from obtaining the position of party leadership. While taking the post of general secretary, Stalin declared the slogan of consolidation of socialism in one country and asked the people of the Soviet Union to be loyal to the communist party and regime.

In 1925 Trotsky resigned from the defence ministry and in 1927, under party disciplinary measures, he was expelled from the party and Politburo, In 1929 he was exiled from Russia and afterwards all his friends and followers were ejected from the party and government organs.

Under a strict order from Stalin all state organs launched an organis- 
ed and systematic propaganda campaign against Trotsky and Trotskyists. Since Stalin had no active civil war role on record, the party directed state scholars now gave him a major role throughout the civil war and the name of Trotsky was absolutely omitted. A new education curriculum was introduced, Trotsky's name was removed from history books, the party, military committee, and the Petersburg Soviet Council. His role and activities during the civil war were attributed to the joint action of the party's central committee. The entire Soviet media 'called him traitor, saboteur, intriguer, foreign agent, and mercenary.

During the Red Terror (1929-39) numerous civilian and military officers were brought to torture cells and many of them were summarily executed. Here I introduce three important trials out of the numerous trials that took place. In one of the trials in 1936, thirtythree high ranking government officials were court martialled. In 1937 one marshall and a great number of generals were shot dead. In the trial of 1938 , twenty one members of the central committee and Politburo were tried and all of them were executed.

In these three trials most of Lenin's comrades in arms, except Trotsky and Stalin himself, were exterminated. Most of the Politburo members, members of the central committee, one prime minister, a few deputy prime ministers, two presidents of international communism, presidents of labour union, one marshall, one chief of staff, many generals, the chiefs of political sections in the military, commanders of garrisons, some Soviet ambassadors in Asia and Europe, two high ranking officers of the political police and some distinguished citizens were tried in the torture cells and many of them were killed after inhuman agonies.

All of them were charged with collaborating with Trotsky to try to kill Stalin, to poison the proletariat class, with reintroducing capitalism in the Soviet Union, and destroying the very economic, political and military foundations of the state.

Everyone of the accused was beaten and tortured before the trial in court. In a popular version of brute police power in the communist system, each of the accused "voluntarily confessed" that all of them, right from the beginning of the revolution, were full members 
of the British, French, Japanese and German spying networks. Ail of them had secret agreements with Nazi Germany and Japan for toppling the Soviet system and surrendering some parts of Russia to these countries.

During the trials, the Soviet intelligence network and party members were on continuous marches, shouting "Shoot these mad dogs".

The "voluntary confessions" of the accused were the only basis of the proceedings and the verdicts. Here I refer to two cases of "voluntary confession". In one case David Holtzman, and Yuri Berman "voluntarily confessed" that they had met Trotsky in a hotel in Copenhagen whore they decided to kill Stalin and some other high ranking communist leaders. But after their execution, it was revealed that the same hotel in Copenhagen had long ceased to exist, and many years before the date of the meeting of the accused with Trotsky it had been turned into a department store. Similarly Piatakov "voluntarily confessed" that he had been the most trusted contact of Trotsky for a long time. He stated that he had flown on a Nazi plane to Oslo where he met Trotsky and delivered all his reports to him in person. He was instructed by Trotsky to deliver his secret messages to his supporters in the Soviet Union against Stalin and communist regime. After his execution, the authorities of an aerodrome near Oslo, where Piatakov had confessed to have landed in a German plane for a meeting with Trotsky, testified that at the time indicated as well as during several months before and after that date no foreign plane had landed there.

"During "the Red Terror" Stalin issued a decree that an affence or crime of a family member was the crime of the whole family. If family members hesitated to hand over criminals and offenders in the family to the police, in such case the entire family would be considered guilty and be punished severely.

Due to sheer fear of Red Terror, many sons, daughters, wives, brothers, sisters, and fathers testified against their family members. On the other hand many accused "voluntarily confessed" their crimes and offences just to save the lives of their family memebrs.

In March, 1939, Stalin while basing his documents and evidence on 
"voluntary confession by the criminals" declared that it was proved that Trotsky had been a foreign agent since the revolution. The traitor had been busily at work to intrigue with foreign spy networks against the very existance of the Soviet Union. For this reason the people of the Soviet Union awarded this traitor the death penalty.

In 1939, Trotsky left Norway for Mexico. Here he was harassed by repeated attempts on his life. All his children diéd in mysterious circumstances. On August 20, 1940, while he was engaged in writing an accusatory biography of Stalin, an agent of the dictator smashed his head with an axe in his residence. When Stalin rid himself of this relentless adversary, he declared all Trotskyists as traitors and Trotskyism as the greatest crime against "scientific socialism". Thus, at the end of the bloody drama featured by Orwell in Animal Farm, Napoleon (Stalin) won against Snowball (Trotsky), the most active pig who led the animals in the battlefields against Jones and his men and drove them out of Manor Farm.

\section{Squealer:}

This is the most intelligent, clever and eloquent orator pig in Animal Farm. He changes and interprets all the written laws in the personal interest of Napoleon and the privileged class of a few pigs. Squealer represuats the huge propaganda machine of the communist regime. This colossal machine presents all the facts as their opposites, deceives all the social segments, makes white black and black white, and inso doing safeguards the interest of the great dictator and privileged new class. For instance, Squealer very skillfully changes all the seven commandments of Animal Farm and to the last one, "All are equal" adds "some are more equal than others".

\section{Boxer, Clover and Banjamin:}

These three characters are the symbolic representatives of different Soviet labourers:

\section{(i) Boxer:}

$\mathrm{He}$ is a very strong horse. He represents the real character of those labourers who believe in the revolutionary, system and infallible leadership. He does not care for his health, working hard day and night. He is wounded in the Rebellion and is awarded a medal for his active participation in the Rebellion and hard work in Animal Farm. 
But when he becomes old, sick and of no use to render further active services to the privileged pigs, then this former hero is sold very cheap to the neighbouring butcher.

\section{(ii) Clover:}

She is a mare sympathetic to Boxer. To her, health is wealth and she often advises Boxer not to involve himself in unnecessary hardwork. She works but not at the expense of her own health.

Whenever she sees that the actions of the pigs are contrary to the seven written commandments, she goes to read them herself and says nothing about the changes to others. She is fully aware that great changes in the seven commandments have been made in the interest of Napoleon and privileged few pigs. She is a witness to all the tyrannies, cruelties, miseries and hunger inflicted upon the working animal by the pigs. She is tight-lipped and never talks about Snowball or his active role in the Rebellion, as Boxer sometimes argues with Squealer. She lives on the farm longer than many other animals.

(iii) Benjamin:

The donkey is the most cautious, clever and silent animal in the farm. He performs his normal work but is never ready to participate in "voluntary work" on holidays or overtime. He knows all about the repressive results of the Rebellion, the deceiving tactics used by the privileged pigs who have declared themselves the mental workers of the farm. Boxer is his close friend. He is shocked to see his frined being transported to the slaughter house. Still he endures all these hardships and shocks. He lives a long life on the farm.

\section{Dogs:}

They are the symbol of Stalin's secret police. Under the communist regime, the Soviet Union turns into a police state and the spy networks increase beyond all imagination. This horrible network silences all opponents by killing, torturing or depriving them of their livelihood. Dogs are depicted in this book as a very fierce force of Napoleon which is regarded second to the privileged pigs.

\section{Moses:}

This crow represents the symbol of the clergy in the Soviet Union. As a matter of fact the communist elite have quite different approaches to the old and young generations. Under strict rules and regulations by the communist regime, some of clergymen are appa- 
rently allowed to perform duties for the religious minded older generation. By allowing some clergymen to continue to function, the Soviets want to satisfy the outgoing older generation and to show to outside world their tolerance towards religious practices. However, because of restrictions imposed by the communist regime, the clergymen are not allowed to interfere in political, social or economic affairs of the Soviet state. Though the Soviets organs constantly campaign against all religious ideas, the government gives some material benefits and social status to the practicing religious leaders. Moses is the most hated one by the pigs, but he receives his ration without any work.

\section{Sheep:}

These are the symbols of Stalin's most loyal underlings in the party and spy network, who are often called to disrupt opponent's speeches and criticism in party meetings.

10. Mollie:

This pretty mare represents the dissidents under the communist dictatorship, who flee and seek asylum in foreign countries.

\section{Pigeons:}

These are the symbol of Stalin's propaganda agents in foreign lands.

12. Hens, ducks etc, are the symbols of the destitute toiling peasentry in the Soviet Union.

\section{Foxwood and Pinchfield Farms:}

These two farms are representative symbols of the neighbouring free enterprise capitalist countires. On the one hand the owners of the farms are afraid of the rebellions of the animals in their farms to be instigated by the pigs of Animal Farm and on the other hand the rival owners of the neighbouring farms compete for the material gains available from dealing with Animal Farm. Similarly, the capitalist countries are diametrically opposed to the communist ideology but each one of these countries tries its best to have access to Soviet markets.

14. In the last chapter of the book the author draws interesting conclusions about the complete changes in the commandments, the 
emergence of absolute dictatorship, and a privileged new class. At the end he shows how the self-appointed communist party "of the proletrariat" exploits and suppresses the proletariat, and how the former Tzarist empire is replaced by a socialist empire - the land of cruel dictators and oppressors.

Translated into English 


\section{WRITERS OF THE ARTICLES}

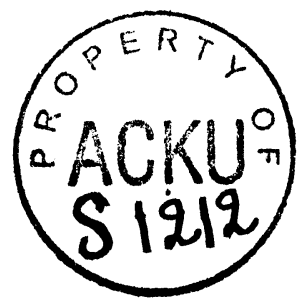

Major. Nasrullah Safi, specialist on military science, Moscow, and guerrilla warfare, Egypt, former member of general directorate of planning and operation defence ministry, member of WUFA.

A. Rasul Amin, M.A. political science, Peshawar University, former chairman of social sciences departments, Kabul University, director of WUFA.

Dr. Z.A.Mumtaz, Ph.D. political sciences, Aliharh Muslim University, India, former director of foreign liaison, Kabul University, member of WUFA.

Jamila Luickx and Dr. G.J. Wennink are members of the board of the Dutch foundation "Help the Afghans" in The Hague, Holland, Jamilla Luijckx has visited the frontier area of Afghanistan and Pakistan.

Dr.G.J. Wennik visited Afghanistan repeatedly for business reasons in the sixties and seventies.

Mohammad Hakim Aryubi. M.A. international law and organisations, State University Colorado, USA, former diplomat who has served as Afghanistan's representative to the UN (1969-1973) and as Consul General at Karachi, Pakistan (1974-1978).

Ahmad Yusuf Nuristani, Ph.D., candidate, Near Eastem Studies USA, former member of teaching staff social sciences department, Kabul University, member of WUFA.

Hakim Taniwal, M.A. Sociology, West Germany, former member of teaching staff, social sciences department, Kabul University, member of WUFA.

Mohammad Asef Ikram, B.Sc, mechanical engineering, Kabul University, former technical staff member of the directorate of data processing, Central Statistics Office, ministry of planning. 


\section{Serial$$
\text { DS }
$$$$
37.2
$$$$
\text { 183 }
$$ \\ "Though my soul will go to God, my spirit will remain in Afghanistan. My last words to you my son and successors are: Never trust the Russians."}

ABDUR RAHMAN KHAN

The Iron Amir of Afghanistan 